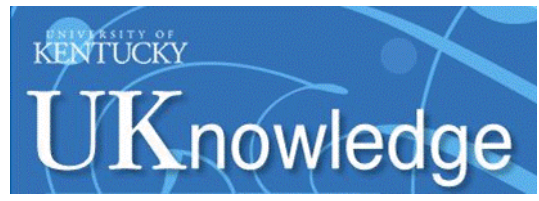

University of Kentucky

UKnowledge

2016

\title{
The Ethics of Visual Legal Rhetoric
}

\author{
Michael D. Murray \\ University of Kentucky Rosenberg College of Law, michael.murray1@uky.edu
}

Follow this and additional works at: https://uknowledge.uky.edu/law_facpub

Part of the Legal Writing and Research Commons

Right click to open a feedback form in a new tab to let us know how this document benefits you.

\section{Repository Citation}

Murray, Michael D., "The Ethics of Visual Legal Rhetoric" (2016). Law Faculty Scholarly Articles. 651.

https://uknowledge.uky.edu/law_facpub/651

This Article is brought to you for free and open access by the Law Faculty Publications at UKnowledge. It has been accepted for inclusion in Law Faculty Scholarly Articles by an authorized administrator of UKnowledge. For more information, please contact UKnowledge@lsv.uky.edu. 


\section{The Ethics of Visual Legal Rhetoric}

\section{Notes/Citation Information}

Michael D. Murray, The Ethics of Visual Legal Rhetoric, 13 Legal Comm. \& Rhetoric: JALWD 107-155 (2016). 


\title{
The Ethics of Visual Legal Rhetoric
}

\author{
Michael D. Murray*
}

\section{Introduction: The Visual Brief}

The assertion that one picture can replace a thousand words is hardly remarkable. ${ }^{1}$ But the question of when a picture-or graphic, or video, or other visualization-should replace a thousand words of legal discourse is more complicated. Can (or should) an attorney replace several pages of narrative reasoning with a graphical visualization of the communicationa cartoon, a painting, a photograph, a model, or another form of artistic rendering? Will the legal writing discourse community of judges, practitioners, and legal scholars readily accept graphical work as a substitute for or substantial supplement of traditional textual legal rhetoric?

Several scholars have considered these questions in parts: there is scholarship on the law's lackluster handling of the meaning, use, and effect of images in the law in general; ${ }^{2}$ on the impact of popular culture on the

* Professor Michael D. Murray (J.D., Columbia Law School, Harlan Fiske Stone Scholar) currently is a visiting professor and Telluride Faculty Fellow at the University of Michigan Law School. Previously, he was Associate Professor of Law at Valparaiso Law School, and he has taught at the University of Illinois College of Law and Saint Louis University School of Law. Professor Murray has written 21 books and numerous law-review articles on legal rhetoric, advocacy, art law, copyright, ethics of intellectual property, freedom of expression, and other topics. This article benefits from the comments of Steve Johansen (Lewis \& Clark), Stefan Krieger (Hofstra), Jim Sowerby (John Marshall-Chicago), Ann Shields (Washington Univ. St. Louis), and David Ziff (Washington) at the Applied Legal Storytelling Conference V in Seattle; from Sonya Bonneau (Georgetown), Lucy Jewel (Tennessee), Katrina Lee (Ohio State), Carol Parker (Tennessee), Michael Smith (Wyoming), and Adam Todd (Dayton) at the 2014 Legal Writing Institute Biennial National Conference in Philadelphia; from Pamela Keller (Kansas), Allison Kort (UMKC), Kathleen Dillon Narko (Northwestern), Maureen Collins (John Marshall-Chicago), and Joyce Rosenberg (Kansas) at the 2013 Central States Legal Writing Conference at the University of Kansas; and from William Mock (John Marshall-Chicago), Daphne O'Regan (Michigan State), Robert Somers (Whittier), and Charles Thatcher (South Dakota) at the Seventh Global Legal Skills Conference (2012) in San Jose, Costa Rica.

1 But the adage still is worthy of a Harvard Law Review article title. Rebecca Tushnet, Worth a Thousand Words: The Images of Copyright, 125 HARV. L. REV. 683 (2012). With the advent of modern, multimedia imagery, some commentators have expanded the adage to say, "If a 'picture is worth a thousand words', then a computer-generated animation says a thousand words, sings a thousand songs, and paints with a thousand colors all at once." Fred Galves, Where the Not-So-Wild Things Are: Computers in the Courtroom, the Federal Rules of Evidence, and the Need for Institutional Reform and More Judicial Acceptance, 13 HARV. J.L. \& TECH. 161, 190 (2000); David S. Santee, More Than Words: Rethinking the Role of Modern Demonstrative Evidence, 52 SANTA CLARA L. REV. 105, 108 (2012).

2 Tushnet, supra note 1, at 694, 759; Ellie Margolis, Is the Medium the Message? Unleashing the Power of E-Communication in the Twenty-First Century, 12 LEGAL COMM. \& RHETORIC: JALWD 1, 25-27 (2015); Elizabeth G. Porter, Taking Images Seriously, 114 COLUM. L. REV. 1687, 1695-98 (2014). 
nomos (the narrative of law existing in popular culture); ${ }^{3}$ on the presentation of arguments at trial, ${ }^{4}$ and in appellate briefs and judicial opinions; ${ }^{5}$ on evidence-law issues concerning photographs, videos, and visuals; ${ }^{6}$ on cognitive studies and brain science supporting the use of visuals and nonverbal communication; ${ }^{7}$ on law and data visualization; ${ }^{8}$ on the convergence of modern technology in the production of briefs, and the modern phenomena of trial- and appellate-court judges who access and read briefs on electronic devices; ${ }^{9}$ and on the mushrooming topic of narrativity and storytelling in legal work. ${ }^{10}$ My article will connect these lines of

3 A subset of law and popular-culture literature studies the "nomos" See, e.g., Robert M. Cover, The Folktales of Justice: Tales of Jurisdiction, 14 CAP. U. L. REV. 179, 181-82 (1985); Bernard J. Hibbits, Making Sense of Metaphors: Visuality, Aurality, and the Reconfiguration of American Legal Discourse, 16 CARDOZO L. REV. 229, 335-36 (1994); Samuel J. Levine, Halacha and Aggada: Translating Robert Cover's Nomos and Narrative, 1998 UTAH L. REV. 465, 469-70; Kimberlianne Podlas, The Tales Television Tells: Understanding the Nomos Through Television, 13 TEX. WESLEYAN L. REV. 31, 61-62 (2006); Richard K. Sherwin, Nomos and Cinema, 48 UCLA L. REV. 1519, 1538-39 (2001); The Supreme Court, 1982 Term-Foreword: Nomos and Narrative, 97 HARV. L. REV. 4 (1983).

4 Law and popular culture also has studied the movement of visual elements of popular culture into litigation and trial practice. E.g., Evelyn Marcus, Note, The New Razzle Dazzle: Questioning the Propriety of High-Tech Audiovisual Displays in Closing Argument, 30 VT. L. REV. 361, 391 (2006); Rosalind Pollack Petchesky, Fetal Images: The Power of Visual Culture in the Politics of Reproduction, 13 FEMINIST STUD. 263, 265 (1987); Porter, supra note 2, at 1695; Richard K. Sherwin, Visual Jurisprudence, 57 N.Y.L. SCH. L. REV. 11, 16-17 (2013); Richard K. Sherwin, A Manifesto for Visual Legal Realism, 40 LOY. L.A. L. REV. 719, 725-26 (2007); Richard K. Sherwin et al., Law in the Digital Age: How Visual Communication Technologies Are Transforming the Practice, Theory, and Teaching of Law, 12 B.U. J. SCI. \& TECH. L. 227, 243 (2006) (citing STEPHEN M. KOSSLYN, ELEMENTS OF GRAPH DESIGN 10 (1994))

5 E.g., Maria Perez Crist, The E-Brief: Legal Writing for an Online World, 33 N.M. L. REV. 49, 50-51 (2003); Porter, supra note 2, at 1688-90; Philip A. Talmadge, New Technologies and Appellate Practice, 2 J. APP. PRAC. \& PROCESS 363, 370 (2000).

6 E.g., Christopher J. Buccafusco, Gaining/Losing Perspective on the Law, or Keeping Visual Evidence in Perspective, 58 U. MiAmi L. Rev. 609, 621 (2004); K. Preston Oade \& Leslie C. Annand, Winning with Visual Evidence, 25-JAN Colo. Law. 35 , $35-36$ (1996)

7 See, e.g., Michael J. Higdon, Oral Argument and Impression Management: Harnessing the Power of Nonverbal Persuasion for a Judicial Audience, 57 U. KAN. L. REV. 631 (2009); Lucille A. Jewel, Through a Glass Darkly: Using Brain Science and Visual Rhetoric to Gain A Professional Perspective on Visual Advocacy, 19 S. CAL. INTERDISC. L.J. 237, 264-66 (2010); Kathryn M. Stanchi, The Power of Priming in Legal Advocacy: Using the Science of First Impressions to Persuade the Reader, 89 OR. L. REV. 305 (2011); Kathryn M. Stanchi, Playing with Fire: The Science of Confronting Adverse Material in Legal Advocacy, 60 RUTGERS L. REV. 381 (2008); Kathryn M. Stanchi, The Science of Persuasion: An Initial Exploration, 2006 MICH. ST. L. REV. 411 (2006).

8 Jewel, supra note 7 at 264-66; Sherwin, et al, supra note 4, at 268-70. See also DAVID MCCANDLESS, THE VISUAL MisCELlANEum (2012); David McCandless, The Beauty of Data Visualization, TED.COM, http://www.ted.com/talks/david _mccandless_the_beauty_of_data_visualization\#t-323333 (last visited Mar. 15, 2016); EDWARD TUFTE, THE VISUAL DISPLAY OF QUANTITATIVE INFORMATION 13, 40-41 (2d ed. 2001).

9 This trend was noted in the early twenty-first century, and continues today. See Crist, supra note 5, at 50-51; Margolis, supra note 2, at 11-14; Talmadge, supra note 5, at 370; Michael Whiteman, Appellate Court Briefs on the Web: Electronic Dynamos or Legal Quagmire?, 97 LAW LIB. J. 467, 484 (2005).

10 See Anthony G. AMsterdam \& Jerome Bruner, Minding THE LaW (2000); JAmes Hillman, ARChETypal PSYCHOLOGY: A BRIEF ACCOUNT (UNIFORM EDITION VOL. 1) (2004) ("By traditional definition, archetypes are the primary forms that govern the psyche. But they cannot be contained only by the psyche, since they manifest as well in physical, social, linguistic, aesthetic, and spiritual modes."); CARL G. JUNG, THE PORTABLE JUnG 60 (Joseph Campbell ed., R. E. C. Hull trans., Penguin Books 1976) ("Whereas the personal unconscious consists for the most part of complexes, the content of the collective unconscious is made up essentially of archetypes."). MARTHA C. NUSSBAUM, POETIC JUSTICE: THE LITERARY Imagination and Public Life (1995); Teresa Godwin Phelps, Shattered Voices: LANGuage, ViolenCe And The WORK OF TRUTH COMMISSIONS (2004); Ty Alper, et al., Stories Told and Untold: Lawyering Theory Analyses of the First Rodney King Assault Trial, 12 CLINICAL L. REV. 1 (2005); Philip N. Meyer, Desperate for Love: Cinematic Influences Lipon a 
convergence ${ }^{11}$ into a single discussion regarding the ethical creation of legal documents that reflect the convergence-namely highly visual legal briefs that carry out the goals of rhetoric and narrativity, and also meet professional responsibilities.

This article discusses both visual rhetoric and visual narrativity. Visual rhetoric is the use of graphics, photographs, and other depictions for communication, for construction of knowledge and understanding, and ultimately for persuasion in the truth and rightness of the communication. ${ }^{12}$ Narrativity, which is sometimes described as narrative reasoning or storytelling, ${ }^{13}$ is the modern movement to focus our legal writing on the tools that best communicate our clients' stories-their situation, conditions, and circumstances-along with the "story" of the development, growth, and meaning of the law itself that provides the context for the clients' legal situation. ${ }^{14}$ Communicating the story of the development of the law and the story of a particular legal situation (e.g., a client's case) to various audiences is an essential part of legal education and law practice.

The renewed scholarly interest in visual rhetoric ${ }^{15}$ has been provoked in part by several instances of legal communication employing a graphical or audio-visual storytelling device within the context of a work of legal rhetoric, each of which raise questions as to the efficacy and ethical propriety of the particular visual rhetorical devices used in these cases:

- The five-page cartoon amicus curiae brief submitted in United States v. Apple, Inc. ${ }^{16}$

Defendant's Closing Argument to a Jury, 18 VT. L. REV. 721 (1994); Philip N. Meyer, Making The Narrative Move: Observations Based Llpon Reading Gerry Spences Closing Argument in The Estate Of Karen Silkwood v. Kerr-McGee, Inc., 9 CLINICAL L. REV. 229 (2002); Ruth Anne Robbins, Telling the Client's Story Using the Characters and Paradigm of the Archetypal Hero's Joumey, 29 SEATTLE U. L. REV. 767, 773 (2006); Richard K. Sherwin, Law Frames: Historical Truth and Narrative Necessity in a Criminal Case, 47 STAN. L. REV. 39 (1994); Steven L. Winter, The Cognitive Dimension of the Agony Between Legal Power and Narrative Meaning, 87 MiCH. L. REV. 2225, 2228 (1989).

11 I have previously written of this convergence: Michael D. Murray, Visual Rhetoric: Topics of Invention and Arrangement and Tropes of Style, 21 LEG. WRITING___ at 2-3 (forthcoming 2016), available at http://ssrn.com/abstract=2491911; Michael D. Murray, Leaping Language and Cultural Barriers with Visual Legal Rhetoric, 49 U.S.F. L. REV. F. 61 (2015) (Law Review Forum), http://lawblog.usfca.edu/lawreview/wp-content/uploads/2015/07/Murray_FinalforForum_Guney.pdf.

12 See Murray, Visual Rhetoric, supra note 11, at 18; Murray, Leaping Language, supra note 11, at 64-65.

13 Daniel A. Farber \& Suzanna Sherry, Telling Stories Out of School: An Essay on Legal Narratives, 45 STAN. L. REV. 807, 820-24 (1993); Derek H. Kiernan-Johnson, A Shift to Narrativity, 9 LEGAL COMM. \& RHETORIC: JALWD 81, $93-95$ (2012). See also generally, articles in Symposium, Legal Storytelling, 87 MiCH. L. REV. 2073 (1989).

14 Christy H. DeSanctis, Narrative Reasoning and Analogy: The Untold Story, 9 LEGAL COMM. \& RHETORIC 149, 150-51 (2012); Stephen Paskey, The Law Is Made of Stories: Erasing the False Dichotomy Between Stories and Legal Rules, 11 LEGAL COMM. \& RHETORIC: JALWD 51, 52-53 (2014).

15 See sources cited at notes $2,4,5,7,8,11,12,13,14$, supra.

16 No.1:12-CV-2826 (DLC), Document 110 (S.D.N.Y., Sept. 4, 2012), available at http://lawandthemultiverse.com /wp-content/uploads/2012/09/Kohn-Amicus-Brief.pdf (last visited Mar. 16, 2016), and copy on file with the author. 
- The purely visual arguments asserted in the Apple, Inc. v. Samsung patent-infringement litigation, in which Apple alleged, inter alia, that its contractor, Samsung, violated Apple's patent on the overall visual design and functionality of the iPhone. ${ }^{17}$

- The four-page summary judgment brief submitted by the Dallas Mavericks in the Hillwood Investment Properties v. Radical Mavericks Management case, ${ }^{18}$ sometimes referred to as Mark Cuban's "f- you brief." 19

- The Ethics and Public Policy Center's amicus curiae brief in Van Orden v. Perry, which was submitted to support the State of Texas's argument that a Ten Commandments monument on the grounds of the Texas state capitol building did not represent an unconstitutional government endorsement of religion and had a valid secular purpose. $^{20}$

- The use of patrol-car-dashboard-camera video for rhetorical purposes in cases such as Scott v. Harris (2007), ${ }^{21}$ and probable use of the dashboard-or jail-surveillance video in the pending case of Sandra Bland v. Officer Brian Encinia and the Texas Dep't of Public Safety. ${ }^{22}$

"The use of attorney-generated visual devices depicting the prosecutors' theories of the case in closing arguments in the prosecutions of Michael Skakel (in which Skakel, a Kennedy cousin, was prosecuted decades after the fact for the murder of a neighbor), and of Amanda Knox (an American expatriate in Italy, charged with complicity in the murder of her roommate).

In each of the above cases, visual rhetorical devices were employed to communicate with and convince a judge or jury of the rightness (justness)

17 Apple, Inc. v. Samsung Electronics Co., Ltd., No. 12-CV-00630-LHK (N.D. Cal. Apr. 15, 2011). See Ryan H. Flax, Demonstrative Evidence \& Storytelling: Lessons from Apple v. Samsung, THE LITIGATION CONSULTING REPORT (Aug. 23, 2012, 10:29 AM), http:/www.a2lc.com/blog/bid/58997/Demonstrative-Evidence-Storytelling-Lessons-from-Apple-vSamsung.

18 No. 10-05639, 2011 WL 2533342 (Tex. Dist. Ct. June 22, 2011).

19 See images at https://htm11-f.scribdassets.com/7e8b51nh8g10it4f/images/1-4c668ead2b.jpg, or http://deadspin.com /5814499/the-brilliant-legal-mind-behind-mark-cubans-fuck-you-brief, last visited March. 16, 2016. The brief is four pages long, with one full page taken up only by the law firm's signature block and certificate of service.

20 Br. for the Ethics \& Public Policy Center as Amicus Curiae in Support of Resp'ts, Van Orden v. Perry, 545 U.S. 677 (2005), available at http://www.eppc.org/docLib/20050204_decalogue.pdf (last visited Mar. 16, 2016).

21550 U.S. 372 (2007).

22 Reed-Veal ex rel. Bland v. Encinia, 4:15-CV-02232 (S.D. Tex. Aug. 4, 2015). Complaint available at https://cdn2.voxcdn.com/uploads/chorus_asset/file/3933654/Bland_lawsuit.0.pdf (last visited Mar. 16, 2016). 
and correctness of a party's argument. Each case raises questions about whether the use of the device was advisable, effective, and ethical.

In this article, I discuss and critique the issues of efficacy and advisability raised by the use of visual rhetorical devices in a communicative and evidentiary sense, ${ }^{23}$ and further examine the special ethical and professional-responsibility issues created by the unusual emotive, communicative speed and power of visual rhetorical devices. Later, I focus on the particular examples listed above, ${ }^{24}$ and discuss the rhetorical efficacy and ethical propriety of the uses of the visual rhetorical devises in these particular examples.

\section{Visual Legal Rhetoric's Power to Mislead and Confuse the Audience}

The power of visual rhetorical devices to communicate comes bundled with a very real potential for harm: while the devices can communicate powerfully on an intellectual and emotional level, they also can be manipulated to deceive. Visual media are ethically neutral. There is nothing inherently deceptive about a particular visual medium, but the ethics of the advocate using the visual medium are immediately implicated by the decision whether or not to employ a visual form of communication in the particular rhetorical situation of the case. This potential for confusion and harm is the subject of this section.

\section{A. Photos Do Not Lie, but Liars Use Photos}

The famous photographer, Richard Avedon, once stated, "There is no such thing as inaccuracy in a photograph. All photographs are accurate. None of them is the truth." 25 This pithy comment suggests caution in the use of photographs, depictions, and other visual material in legal discourse when the use of such visuals might lie or distort reality. It is not the photograph or the photographic medium that lies; it the author of the work who creates the scene depicted in the photograph using the tools of her trade-the camera and the darkroom equipment or software that produces the final displayed image. An advocate might not be the one to create the image, but she might choose a deceptive or misleading visual to bootstrap her argument. 
A recent example reveals one aspect of the potential for trickery of photography: From February 24 through 27, 2015, a photograph of a blueand-black, $\$ 76$, off-the-rack dress in the U.K. received 16 million viewings in a six-hour period after posting, and 28 million viewings overall, simply because an amateur photographer had managed to capture an image of the dress in unusual lighting ${ }^{26}$ that made the blue-and-black dress appear to be white and gold to many viewers. ${ }^{27}$
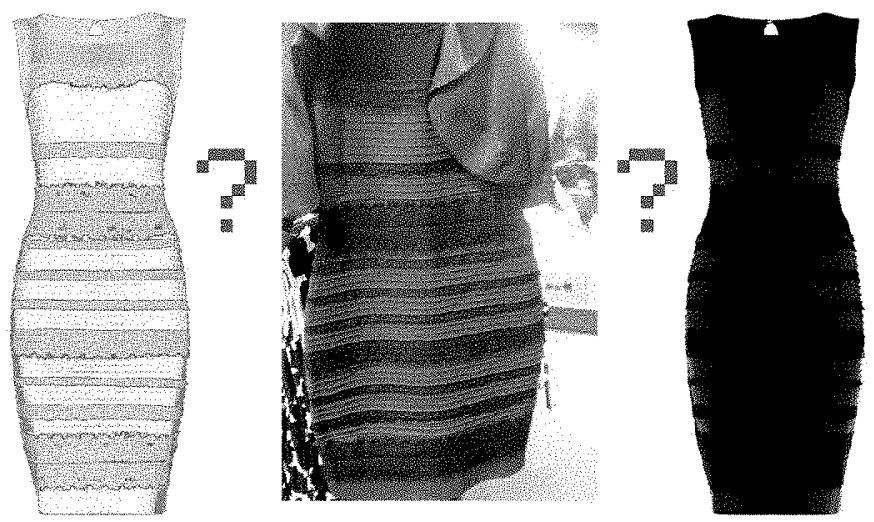

The illusion was caused by the eye's perception mediated by clues of foreground lighting and backlighting, and the interpretation of shadows. These factors caused some viewers to swear with certainty that the dress was white and gold, while others swore with equal certainty that the dress was its actual colors of blue and black. ${ }^{28}$

This incident is a reminder that human perception is relative to each viewer and therefore that the messages communicated by visual mediaeven a simple, amateur photograph of a dress-require a certain amount of interpretation to ensure that the message is not perceived in a manner that obfuscates or overtly lies as to the actual message of the image. Visual rhetorical devices do not carry or communicate a single message to all users. They are not static, independent bearers of unambiguous truth. The same can be said, of course, of all communicative media. Letters are symbolic instruments that are combined and interpreted as forming words, which are further combined and interpreted as forming a language

26 Similar composite of images depicting the white-gold, blue-black dress illusion at https://i.ytimg.com/vi/ UULDKK3vmvA/maxresdefault.jpg; and http://img.youtube.com/vi/UULDKK3vmvA/0.jpg.

27 Jonathan Mahler, The White and Gold (No, Blue and Black!) Dress That Melted the Internet, N. Y. TIMES (Feb. 27, 2015), http://www.nytimes.com/2015/02/28/business/a-simple-question-about-a-dress-and-the-world-weighs-in.html?_r=0; Leslie Shaffer, The Dress that Broke the Internet, CNBC (Feb. 27, 2015, 7:28 AM ET), http://www.cnbc.com/id/102461771\# (noting that, at one point, 670,000 people were viewing the dress simultaneously on Buzzfeed, breaking all previous records for simultaneous viewing on the site).

28 See Karen Weintraub, Blue or White Dress? Why We See Colors Differently, NATIONAL GEOGRAPHIC (Feb. 27, 2015, 8:46 PM EST), http://news.nationalgeographic.com/news/2015/02/150227-blue-white-dress-optical-illusion-science/. 
that attempts to communicate clearly and objectively, but every language is susceptible to the propagation of ambiguities that plague both legal and nonlegal communication. ${ }^{29}$ With visual communication, the ambiguities might be more subtle, while the communication of the message (clearly or ambiguously) happens even more rapidly than with words. Nevertheless, the law often must regulate and accommodate visual media as if it has an "objective appearance" when used for factual proof or rhetorical argument in legal communication.

\section{B. What's Evidence Law Got to Do with It?}

This article focuses on the ethical use of visual-graphical imagery as topoi of invention (demonstration of a point of argument) or arrangement (organization, formatting, or presentation of information), or as a trope of style (metaphors or other figures of speech) within legal discourse. ${ }^{30}$ The discussion focuses not on the use of visual-graphical items as proof of facts but rather as communication of legal rhetoric within legal discourse. ${ }^{31}$ However, all lawyers are aware that visual imagery also can be used for proof of the truth or existence of certain facts in lawsuits. The legal issues of honesty vs. deception in visual rhetoric coincide with but are not fully addressed by the law of evidence regarding the admissibility of photographs, depictions, and graphical images as proof of facts in litigation. In this section, I intend to drive home the distinction between offering visuals in litigation documents in order to prove the very subject matter of the dispute and using visuals in legal argument and discourse for a rhetorical, communicative function. Evidence law addresses the former use well, but it is not sufficient to address the latter point, which is one of the reasons for this article.

29 A fact that keeps lawyers in business, by the way.

30 The specific examination of visual rhetorical devices as topics of invention and arrangement and tropes of style under modern argument theory is found in Murray, Visual Rhetoric, supra note 11.

31 I stand by my assertion that I deal here with rhetoric and not proof of facts, but this very statement can be unpacked further. Beginning in the 1950s, Stephen Toulmin and Chaim Perelman asserted that all truth is relative. Kristen Konrad Robbins, Philosophy v. Rhetoric in Legal Education: Understanding the Schism between Doctrinal and Legal Writing Faculty, 3 J. ALWD 108, 123 (2006). See, e.g., STephen E. Toulmin, Uses of ARgument 163-73 (2003); Chaim Perelman, The REALM OF RHETORIC 41-44 (William Kluback trans., 1982); Toulmin argued that people in everyday life do not use Aristotelian logic to establish conclusive proof, but rather use "informal logic" to reason and to acquire knowledge. STEPHEN TOULMin, Richard RICKE, \& ALLAN JANIK, INTRODUCTION TO REASONING 4-18 (2d ed. 1984). The knowledge acquired and the arguments made are only probable, not absolute. Id. Like Toulmin, Perelman argued that appeals to reason lead only to probable truths: "[The appeal to reason must be identified not as an appeal to a single truth but instead as an appeal for the adherence of an audience ...." FRANCIS J. MOOTZ III, LAW, HERMENEUTICS AND RHETORIC 181 (2010) (citing CHAÏM PERELMAN, THE NEW RHETORIC AND THE HUMANiTIES 13-14, 48-50 (William Kluback trans., 1979)). 

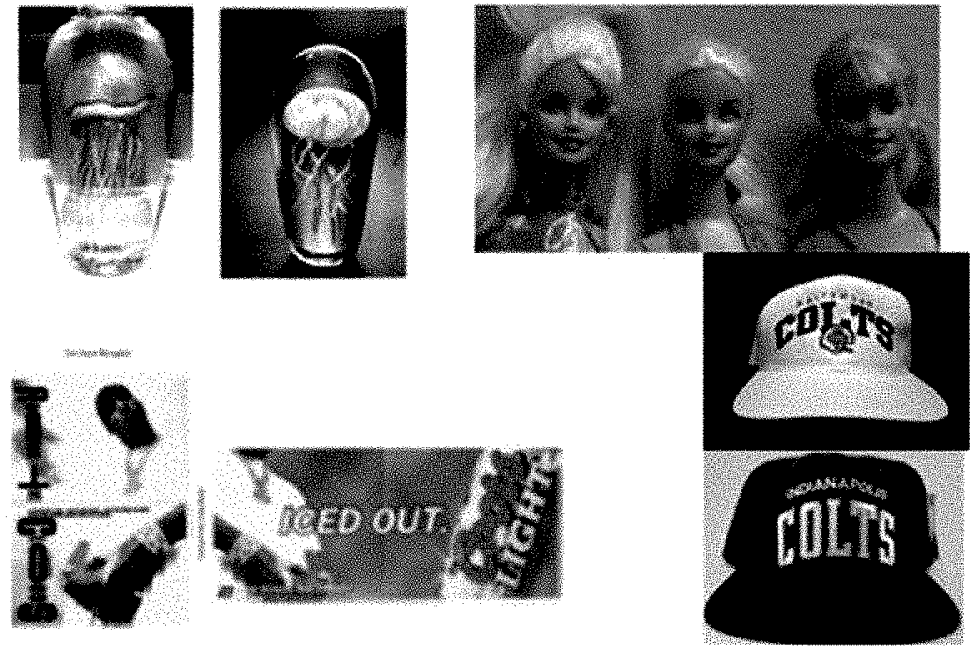

Evidence law concerns itself, appropriately, with "evidence"-the presentation of factual material or material making the existence of facts more or less likely. ${ }^{32}$ For example, visuals of the two works in a copyright dispute over an allegedly infringing work are offered as proof and illustration of the very subject matter of the dispute: ${ }^{33}$

Evidence law controls issues regarding visuals purporting to depict the actual subject matter of a suit when offered to prove the quality, nature, and appearance of this subject matter, or at least its existence. The actual subject matter of a suit that would be proved with visual evidence might range from a depiction of a contract of sale, or the items seized in a child-pornography prosecution, or a visual inventory of the assets possessed by a debtor, or other visual-graphical images offered as facts or as proof or rebuttal of facts.

In contrast, visual images may be used not as proof of facts, but in a consciously rhetorical manner to represent a point of communication or argument. They might symbolically represent an emotion: ${ }^{34}$

32 See Fed. R. Evid. 401; United States v. Mehanna, 735 F.3d 32, 60 (1st Cir. 2013); United States v. Abu-Jihaad, 630 F.3d 102, 132 (2d Cir. 2010).

33 Images of exhibits relating to copyright infringement suits, are, clockwise, photographs of two glass-in-glass sculptures from the court's opinion in Satava v. Lowry, 323 F.3d 805 (9th Cir. 2003); photograph by Michael D. Murray illustrating the comparison of Barbie faces in Mattel, Inc. v. Goldberger Doll Mfg. Co., 365 F.3d 133 (2d Cir. 2004); photographic collage by Michael D. Murray illustrating the comparison of hats depicting competing NFL and CFL logos of the Colts franchises in Indianapolis Colts, Inc. v. Metro. Baltimore Football Club Ltd. P'ship, 34 F.3d 410 (7th Cir. 1994); photographs of the Mannion original and the Coors advertisement from the court's opinion in Mannion v. Coors Brewing Co., 377 E. Supp. 2d 444 (S.D.N.Y. 2005).

34 Image depicting "tears of joy," derived from the photograph available at https://kpwebster.files.wordpress.com /2015/08/tears_of_joy.jpg. 


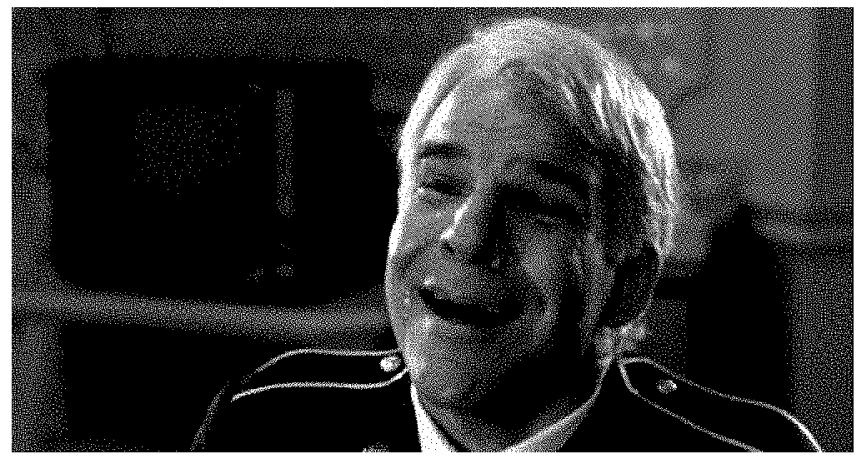

They might illustrate what is meant by the allegation that "excessive force was used to clear the crowd":35

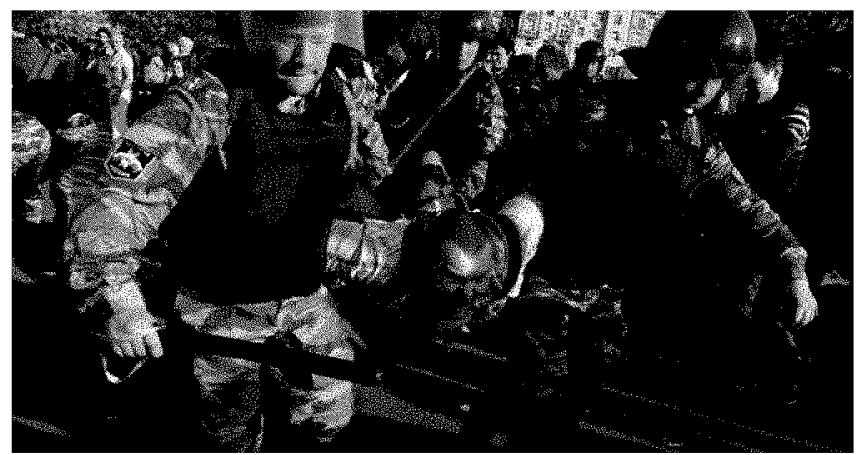

They might be used metaphorically to explain a more abstract concept, such as jealousy or hurt feelings: ${ }^{36}$

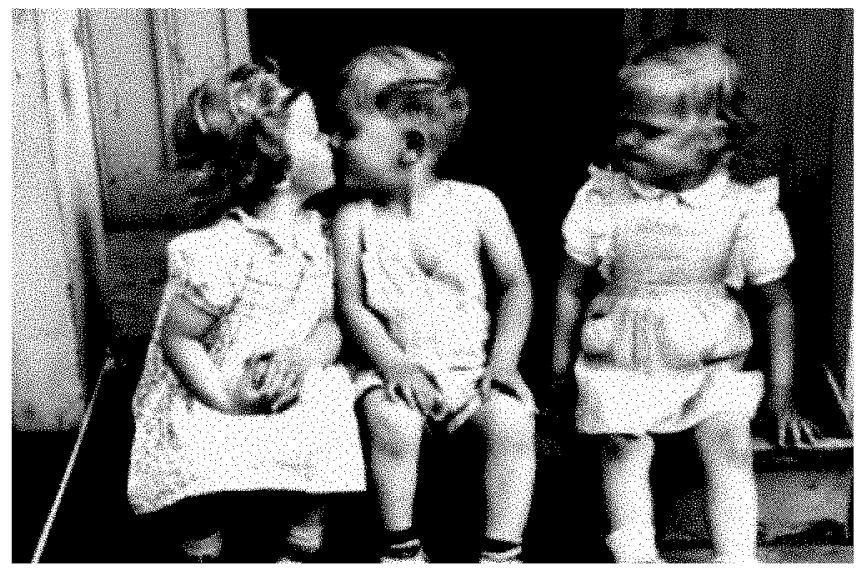

35 Image depicting the forceful measures used to clear a protest in Moscow, derived from photograph $(2012$ Agence France-Presse/Getty Images, available at http://www.cnn.com/2012/05/06/world/europe/russia-protest/.

36 Image depicting the jealousy of one child concerning two other children who are kissing, derived from the photograph available at http://www.unk.com/blog/wp-content/uploads/2014/05/jealousy.jpg. 
Evidence law is justifiably cautious when it comes to visual evidencenamely proof of facts by demonstration or depiction. Visual and audio evidence comes in many forms: photographs, video recordings, audio recordings, and other graphical, digital, and analog recordings or depictions that purport to represent actual things and events in the world. There are two uses as evidence-substantive proof of a fact (also known as "real evidence") vs. demonstration or illustration of a witness's testimony, often an eye witness or expert witness ("demonstrative evidence"). ${ }^{37}$

The distinction between real evidence and demonstrative evidence is not based on fixed categories but rather on how the evidence is going to be used. For example, a letter could be used several ways, some of which are verbal, some nonverbal; some are demonstrative, and others are substantive:

- A letter may be used to show an actual item that was stolen in a burglary; this is substantive, real evidence, the actual thing is proffered as the very thing that was burgled. ${ }^{38}$

- The letter may be used demonstratively to illustrate a witness's testimony. Perhaps the

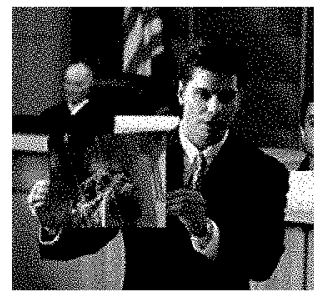
witness is testifying that two historic documents were delivered to a museum, one of which appeared to be damaged with a gradually yellowing coloration in the margins of the paper. The letter is perhaps being used as an exemplar of what the witness means by "a gradually yellowing coloration." The letter is not offered as proof of "gradually yellowing coloration." It is just an illustration of

37 See 22 KENNETH W. GRAHAM, JR., ET AL., FED. PRAC. \& PROC. EVID. \$ 5174.1, 5174.2, 5174.4 (2d ed. 2015); Santee, supra note 1 , at $110-24$.

38 Image depicting a man holding up a document in court, derived from the original photograph available at http://cluesforum.info/viewtopic.php?p=2367625. 
what the witness observed and what it means to the witness. The witness's testimony is the real evidence, subject to normal confrontation and challenges. ${ }^{39}$

- The words of the letter might be offered as a statement for proof of the matters stated in the letter. Now the letter itself is just a transmitter of verbal testimonythe letter itself is not the evidence, it is the statements in the letter that are the real evidence, and they are subject to the usual challenges for hearsay and other evidentiary rules and requirements for testimony. $^{40}$

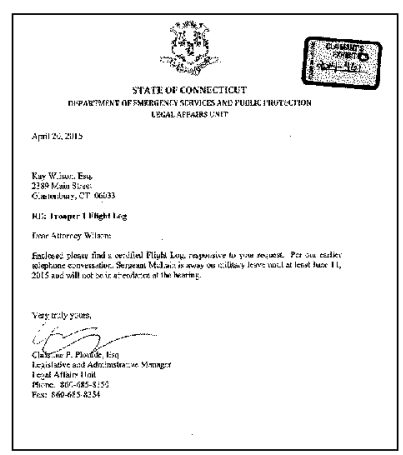

A nonverbal, visual example, such as a photograph, presents the same possibilities:

- A photo may be proffered as substantive evidence that it is a genuine work of a famous photographer. Once established as a genuine work, the same photo could be used demonstratively to illustrate the testimony of an expert witness who is explaining how a genuine work of this photographer (the photo) differs from a forgery by comparing the photo to the alleged forgery. ${ }^{41}$

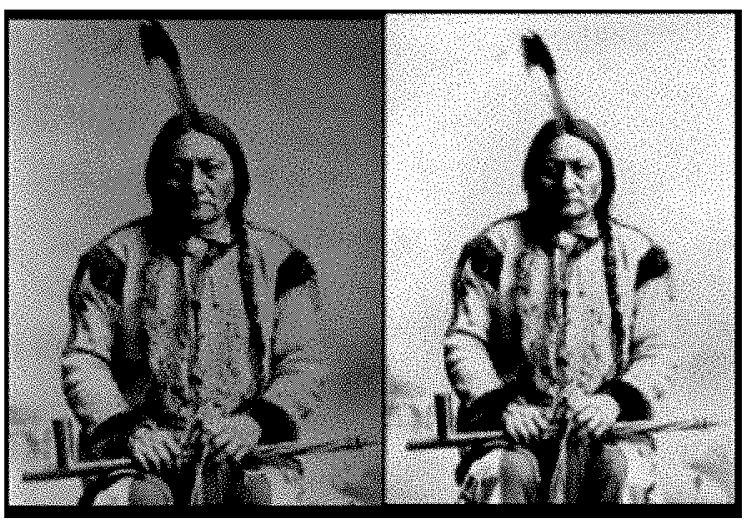

39 Images of documents shown side by side to illustrate the decay and yellowing of the one compared to the other, derived from the original photograph available at https://en.wikipedia.org/wiki/Birmingham_Quran_manuscript\# /media/File:Birmingham_Quran_manuscript.jpg.

40 Image of a letter marked as a litigation exhibit, derived from the original photograph available at http://2.bp.blogspot.com/-bqMF7gPDMOU/VlOAttAdPMI/AAAAAAAABMU/V4bxsSf-Q3I/s1600/exhibit\%2BO.PNG.

41 Photographs of Sitting Bull shown side by side to illustrate the differences between the two photographs, derived from original photographs available at http://www.oldsantafetradingco.com/assets/site-images/sitting-bull-with-pipe.jpg (left), and http://www.nativeartstrading.com/images/DSCN_Sitting\%20Bull.jpg (right). Note that neither of the sources from which the illustration is derived is alleged to be a forgery. 
- A photo may be proffered as evidence that it is a record accurately showing the defendant at the counter of a liquor store during the robbery; the photo is offered as substantive proof of the matter depicted. ${ }^{42}$

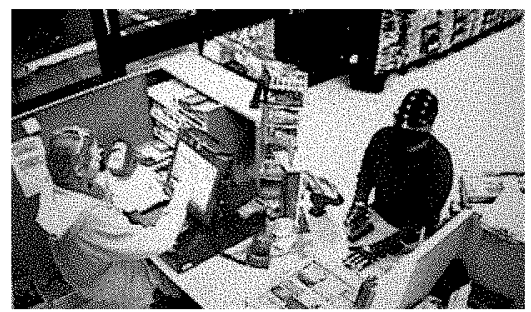

- A photo may be used as an illustration of a witness's testimony that the back door of the liquor store never closed properly; it always left a gap. Now, the photo is not offered as substantive evidence. The witness's testimony is the substantive evidence, and the photo illustrates what the witness means when he describes "not closed properly" and a "gap." 43

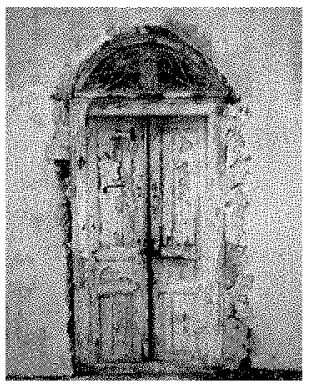

When visuals are offered demonstratively to illustrate other testimony or offered substantively as proof of the matter depicted or presented in the evidence, the proffer of the evidence implicates at least three evidence rules: Fed. R. Evid. 401 (relevance), 403 (not prejudicial or misleading), and 901 (properly authenticated). If the use further purports to introduce testimonial evidence-for example, if either the recording or depiction actually contains written or spoken testimony, or the use substitutes for testimony of an absent witness (e.g., "In effect, this video shows what [the absent witness] was talking about.")-then the evidence is further subject to hearsay rules, Fed. R. Evid. 801-807.

First, Rule 401 demands that the matter be relevant-able to make the existence of a fact relevant to the matter more or less likely.44 When used substantively, the visual evidence must actually prove or help to prove or disprove something that is relevant to the case. When used demonstratively, the visual evidence must help to illustrate a portion of the witness's testimony that is relevant, or explain or highlight other real evidence that is relevant to the case. Thus, part of the proffer of visual evidence requires the proponent to establish that the recording or depiction does show actual facts or events, and that the facts or events are relevant to the matter.

42 Photograph depicting a man at a convenience-store counter, wearing a mask and holding a gun, derived from the original photograph available at http://216.157.37.6/sheriff/press/2011press_releases/january/110001_1_lg.jpg.

43 Photograph depicting a door that is not properly closed and showing a gap, derived from the original photograph available at https://s-media-cache-ak0.pinimg.com/236x/d7/d1/ab/d7d1abff411c9524bb22deaed07561e1.jpg.

44 Fed. R. Evid. 401 states, "Evidence is relevant if: (a) it has any tendency to make a fact more or less probable than it would be without the evidence; and (b) the fact is of consequence in determining the action." 
Visual, nonverbal evidence also must meet the standards of Fed R. Evid. 403, which states, "The court may exclude relevant evidence if its probative value is substantially outweighed by a danger of one or more of the following: unfair prejudice, confusing the issues, misleading the jury ..." ${ }^{45}$ In applying Rule 403 to visual demonstrations, courts engage in a separate inquiry to evaluate whether a depiction appears to "represent" or "recreate" actual facts or events, such as an accident or other relevant fact or occurrence at issue in the case. ${ }^{46}$ Depictions that appear to represent or recreate actual facts or events are more likely to confuse the jury than depictions that merely illustrate principles relevant to the understanding of the events or occurrences of the case, such as charts, drawings, diagrams, or depictions supporting an expert's analysis and opinion of a case. ${ }^{47}$ Thus, when evaluating demonstrative evidence that closely resembles an actual place or attempts to recreate the actual events of a case (e.g., the accident, the injury, the crime itself), courts generally require the proponent to establish that the demonstration shares substantial similarity with accident conditions. ${ }^{48}$ In contrast, if a demonstration does not appear to represent or recreate facts or events, Rule 403 generally does not require a foundational showing of similarity with the fact's or event's actual conditions. ${ }^{49}$

Evidence law's requirements do not come down to simply labeling the use "representational" or "non-representational"; instead, they require a careful examination and evaluation as to whether the demonstration is sufficiently close in its recreation or depiction of the original event to create the risk of misunderstanding by the jury. If the demonstration suggests that the litigant is presenting actual facts and events or the recreation of actual facts or events, then the litigant must show that the demonstration is fully supported by the actual facts and conditions of the scene. ${ }^{50}$

If visual and graphical works are offered to prove facts, then the works must be authenticated under Fed. R. Evid. 901. The evidence must be authenticated to establish that the evidence is what it is offered to be.

45 Fed. R. Evid. 403. See Altman v. Bobcat Co., 349 Fed. Appx. 758, 763-64 (3d Cir. 2009) (applying Rule 403 to computer animation that was used to illustrate expert testimony).

46 Altman, 349 Fed. Appx. at 763.

47 See, e.g., id; Hinkle v. City of Clarksburg, 81 F.3d 416, 425 (4th Cir. 1996) (computer animation showing one party's version of events); Harkins v. Ford Motor Co., 437 F.2d 276, 278 (3d Cir. 1970) (expert's testimony about experiment recreating the accident not prejudicial when limited to general principles of physics rather than results of the experiment).

48 E.g., Altman, 349 Fed. Appx. at 763; McKnight ex rel. Ludwig v. Johnson Controls, 36 F.3d 1396, 1402-03 (8th Cir. 1994).

49 See, e.g., Altman, 349 Fed. Appx. at 763; Gilbert v. Cosco, Inc., 989 F.2d 399, 402 (10th Cir. 1993); Champeau v. Fruehauf Corp., 814 F.2d 1271, 1278 (8th Cir. 1987); Harkins, 437 F.2d at 278.

50 Altman, 349 Fed. Appx. at 763; Fusco v. Gen. Motors Corp., 11 F.3d 259, 263-64 (1st Cir. 1993). 
Once again, this is often accomplished by a live witness, who can testify that the facts, items, or events depicted are accurate by first-hand knowledge from observation and experience. If an authenticating witness is available, the witness will vouch for the authenticity and accuracy of the depiction or recording, as recounted in the following example:

Q. Mr. Doe, have you ever been at the intersection of North and Clark Streets?

A. Yes.

Q. How many times have you been there?

A. About fifty times.

Q. Are you familiar with that intersection as it looked on December 13, 2000?

A. Yes, I am.

[Counsel marks exhibit, shows it to opposing counsel, and shows it to the witness.]

Q. I show you what has been marked as Plaintiff's Exhibit \#1 and ask you to examine it. [Witness does so.] Do you recognize the scene in that photograph?

A. Yes.

Q. What scene is shown in that photograph?

A. It shows the intersection of North and Clark Streets.

Q. Mr. Doe, does Plaintiff's Exhibit \#1 fairly and accurately show that intersection as it appeared on December 13, 2000?

A. Yes[,] sir, it does.

At this point, counsel has laid sufficient foundation to enter the demonstrative exhibit in evidence. ${ }^{51}$

However, there is a category of recordings and depictions in which no live witness can speak to the actual events and scenes recorded and depicted: where the agency capturing the recording or depiction is not a person, but a machine. Our modern lives are monitored by many devices, the most common of which in evidence gathering are unmonitored surveillance cameras that record images or video of otherwise unmonitored scenes and events. In cases such as these, the visual or audiovisual work can be a "silent witness" to the information depicted and presented in the work..$^{52}$ But the "silent witness" cannot explain and answer questions

51 This example is taken from Thomas A. MAUET, TrLal TeChniques 191-95 (3d ed. 1992). See also Santee, supra note 1, at 122 .

52 See generally Tracy Bateman Farrell, Annotation, Construction and Application of Silent Witness Theory, 116 A.L.R.5TH 373 (2004); Jordan S. Gruber, Foundation for Contemporaneous Videotape Evidence, 16 AM. JUR. 3D PROOF OF FACTS 493, \$\$ 4-5 (1992); Baker v. State, 87 So. 3d 587, 596-97 (Ala. Crim. App. 2009); Edwards v. State, 762 N.E.2d 128, 136-37 (Ind. Ct. App. 2002), aff'd on reh'g, 768 N.E.2d 506 (Ind. Ct. App. 2002). 
on examination and cross-examination about what it saw and heard. Nor is there anyone else who might have seen the events and occurrences, or the people involved, at the time of recording, who might vouch for its accuracy, ${ }^{53}$ testifying, for example, "Oh yes, this video shows what happened that evening behind the liquor store at 2:00 am. I was there, I saw the whole thing." Therefore, if visual or audio evidence is offered without a sponsoring witness to vouch for the accuracy of the contents of the recording or depiction, a body of law has developed to flesh out the application of the rules of evidence, referred to as the "Silent Witness" rule. With visual and audio evidence, the evidence is said to "speak for itself." ${ }^{4}$ But the authenticity of the evidence must be supported by additional evidence regarding the method of recording, preservation, and retention of records assuring the tribunal that the Silent Witness's recording and retention techniques are sufficiently reliable to produce accurate depictions and recordings of things and events. ${ }^{55}$ Technicians, designers, or operators of the recording equipment might testify to vouch for the authenticity and reliability of the visual or audiovisual recording that is offered.

\section{Evidence Law and Ethical Rules on Honesty}

Evidence law does not answer all of the ethical and professionalresponsibility questions concerning the rhetorical use of visual devices, but evidence law does help to remind us of our ethical responsibility not to put forth false or falsified evidence. Model Rules of Professional Conduct $3.3^{56}$ and $4.1^{57}$ speak directly to the need for attorneys to refrain from

53 E.g., People v. Taylor, 956 N.E.2d 431, 438 (11l. 2011) (an example of a situation where a recording device was set up to be triggered by a motion sensor, and there was no eye witness to vouch for the accuracy of the recording).

54 Id. See also Knapp v. State, 9 N.E.3d 1274, 1282 (Ind. 2014) (describing requirements for admissibility of "silent witness" evidence); State v. Pickens, 25 N.E.3d 1023, 1055 (Ohio 2014) (same). The silent witness theory was originally used in Illinois and elsewhere in connection with the admissibility of X rays. Taylor, 956 N.E.2d at 438 (citing Stevens v. Illinois Central R.R., 137 N.E. 859 (1922); Gruber, supra, note $52, \$ 4$ ). The majority of cases now involve automatic cameras or surveillance systems where videotapes, CDs or DVDs are made from the system and whose admission is sought. Id. (citing Farrell, supra note $52, \$ 2$ (a); Gruber, supra note $52, \$ 25$ ).

55 People v. Mister, 27 N.E.3d 97, 111 (1ll. App. Ct. 2015); Pickens, 25 N.E.3d at 1055; State v. Stangle, 97 A.3d 634, 637-38 (N.H. 2014).

56 ABA Model Rules of Professional Conduct, Rule 3.3, Candor toward the Tribunal, states,

(a) A lawyer shall not knowingly:

(1) make a false statement of fact or law to a tribunal or fail to correct a false statement of material fact or law previously made to the tribunal by the lawyer;

(3) offer evidence that the lawyer knows to be false. If a lawyer, the lawyer's client, or a witness called by the lawyer, has offered material evidence and the lawyer comes to know of its falsity, the lawyer shall take reasonable remedial measures, ...

(b) A lawyer who represents a client in an adjudicative proceeding and who knows that a person intends to engage, is engaging or has engaged in criminal or fraudulent conduct related to the proceeding shall take reasonable remedial measures, including, if necessary, disclosure to the tribunal. 
introducing evidence or testimony that is known to be false. More generally, Model Rule 8.4 states, "It is professional misconduct for a lawyer to: ... (c) engage in conduct involving dishonesty, fraud, deceit or misrepresentation; (d) engage in conduct that is prejudicial to the administration of justice ...." These ethics rules speak to the need to refrain from any conduct that misleads a tribunal or a witness, much as Fed. R. Evid. 403 provides grounds to challenge substantive or demonstrative evidence that will confuse or mislead the finder of fact. The ethics of the employment of visual graphical devices for communication should seek to construct knowledge and understanding for the purpose of communication and persuasion; unethical depiction seeks to obfuscate knowledge, confuse understanding, or overwhelm the audience's ability to decide with the cudgel of deception. Both are possible with visual rhetorical devices, and ethics is necessary to govern the choice made by the attorney employing the devices.

The analysis of admissibility in the evidence sense may help to answer several of the ethics and professionalism questions about the use of images in communications, but a finding of evidentiary admissibility does not fully address the issues of rhetoric and advocacy raised by the use of graphical images as a component of narrative reasoning in discourse. As discussed in the next section, the power of visual rhetoric is in its speed, the strength of reception of visual communication, its transparency, and the biases or heuristics that nearly compel us to accept that what we are seeing is the truth.

\section{Ethical Issues Arising from the Power of Visual Narrativity}

Visual narrative devices work rapidly, almost immediately, to communicate ideas and attain the audience's adherence to the meaning and truth of the ideas communicated and thus to persuade the audience of the truth and propriety of the speaker's communication. Visual imagery is not only faster than words, it is better than words. Brain science demonstrates that images allow greater perception, comprehension, and retention of certain kinds of information. ${ }^{58}$ This section explores how this great power

57 ABA Model Rules of Professional Conduct, Rule 4.1, Truthfulness in Statements to Others, states,

In the course of representing a client a lawyer shall not knowingly:

(a) make a false statement of material fact or law to a third person; or

(b) fail to disclose a material fact to a third person when disclosure is necessary to avoid assisting a criminal or fraudulent act by a client.... 
requires great professional responsibility regarding the use of visual rhetorical devices.

\section{A. With Great Power Comes Great Professional Responsibility}

Visual works not only enjoy an amazing speed of communication with audiences compared to verbal media, they also have an unusual advantage over verbal works in attaining the belief and adherence of the audience to the message of the communication: visuals, such as photographs and videos, generally are perceived by audiences as "showing the truth," as opposed to making an appeal to persuade or manipulate the audience. "The power of images comes not just from the emotions they evoke but also from the linked feature that they are hard to see as arguments: they persuade without overt appeals to rhetoric." 59 Though every image has a purpose, "the most general claims of the discourse are a kind of disclaimer, an assertion of neutrality; in short, the overall function of photographic discourse is to render itself transparent."60

The law has recognized the communicative potential of visual devices from time to time. The most positive, or perhaps better described as "enthusiastic," statements supporting this potential are found in a line of First Amendment cases on symbolic expression that started with the Supreme Court's opinion in West Virginia State Board of Education v. Barnette:

Symbolism is a primitive but effective way of communicating ideas. The use of an emblem or flag to symbolize some system, idea, institution, or personality, is a short cut from mind to mind. Causes and nations, political parties, lodges and ecclesiastical groups seek to knit the loyalty of their followings to a flag or banner, a color or design. The State announces rank, function, and authority through crowns and maces, uniforms and black robes; the church speaks through the Cross, the Crucifix, the altar and shrine, and clerical r[a]iment. Symbols of State often convey political ideas just as religious symbols come to convey theological ones. Associated with many of these symbols are appropriate gestures of acceptance or respect: a salute, a bowed or bared head, a

mentally is as fast as perception of actual visual objects in the world); Carrie Leonetti \& Jeremy Bailenson, High-Tech View: The Use of Immersive Virtual Environments in Jury Trials, 93 MARQ. L. REV. 1073, 1074-75 \& n.18 (2010); ELIZABETH F. LOFTUS, JAMES M. DOYLE \& JENNIFER E. DYSART, EyEWITNESS TESTIMONY: CIVIL AND CRIMINAL (5th ed. 2015) (visual evidence, eyewitness testimony, and perception); ELIZABETH LOFTUS \& KATHERINE KETCHAM, WITNESS FOR THE DEFENSE 14-30 (1991) (visuals and the "Magic of the Mind"); EyEWITNESS TESTIMONY: PSYCHOLOGICAL PERSPECTIVES 272 (Gary L. Wells \& Elizabeth Loftus eds., 1984) (word choice and the use of images affect juror perception).

59 Tushnet, supra note 1 , at 692.

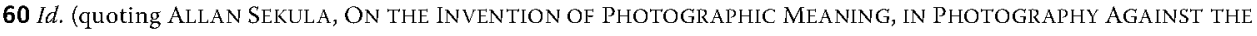
GRAIN 37 (1984)). 
bended knee. A person gets from a symbol the meaning he puts into it, and what is one man's comfort and inspiration is another's jest and scorn. ${ }^{61}$

There is a counterargument. Courts have sometimes dwelled on the power of visual images to confuse and prejudice an audience, as in the case Mutual Film Corp. v. Industrial Commission of Ohio:

[Moving picture exhibitions] may be used for evil, and against that possibility the statute was enacted. Their power of amusement, and, it may be, education, the audiences they assemble, not of women alone nor of men alone, but together, not of adults only, but of children, make them the more insidious in corruption by a pretense of worthy purpose or if they should degenerate from worthy purpose. Indeed, we may go beyond that possibility.....

They are mere representations of events, of ideas and sentiments published and known; vivid, useful, and entertaining, no doubt, but, as we have said, capable of evil, having power for it, the greater because of their attractiveness and manner of exhibition. It was this capability and power, and it may be in experience of them, that induced the state of Ohio, in addition to prescribing penalties for immoral exhibitions, as it does in its Criminal Code, to require censorship before exhibition, as it does by the act under review... ${ }^{62}$

Although science had not yet studied and recorded the effects of visual rhetoric in 1915, the Supreme Court in this quote from Mutual Film is describing the effects of what contemporary cognitive studies and brain science refer to as naïve realism ${ }^{63}$ or cognitive illiberalism ${ }^{64}$ in one viewing imagery. The fact that images are viewed as transparent receptacles of reality disguises the fact that every image has an author, and every author creates the image. ${ }^{65}$ The verbs used-compose, frame, capture, depict, render-might disguise some of the creative role of the author, but

61319 U.S. 624, 632-33 (1943).

62236 U.S. 230, 241-42, 244-45 (1915).

63 See Adam Benforado \& Jon Hanson, Nä̈ve Cynicism: Maintaining False Perceptions in Policy Debates, 57 EMORY L.J. 499, 513-14 (2008); Bryan D. Lammon, What We Talk about When We Talk about Ideology: Judicial Politics Scholarship and Naive Legal Realism, 83 ST. JoHN'S L. REV. 231, 241 (2009); Lee Ross \& Donna Shestowsky, Contemporary Psychology's Challenges to Legal Theory and Practice, 97 NW. U. L. REV. 1081, 1090 (2003).

64 Dan M. Kahan, et al., Whose Eyes Are You Going to Believe? Scott v. Harris and the Perils of Cognitive Illiberalism, 122 HARV. L. REV. 837, 838 (2009).

65 E.g., NeAl Feigenson \& Christina Spiesel, LAW on Display: The Digital TRansformation of LEGAL PERSUASION AND THOUGHT 9 (2009) ("People tend (again, initially and unreflectively) to conflate representations with direct perceptions of reality, to 'look through' the mediation at what is depicted. To see the picture is to see the real thing, unmediated. What a picture depicts just seems to have presence, a kind of being in the world. As a consequence, the meaning 
creation is what occurs. ${ }^{66}$ Every visual work reflects the perspective and point of view of an author. The elements that are to be included in a visual work, and the elements that will be excluded, are all under the direction and control of the author. In short, the very meaning of every photo is under the control of an author. But naive realism-the bias or heuristic that controls the cognitive side of our visual perception so that we believe that what we are seeing in the world is actually there, that it is actually "true" - carries over to believing that what we are seeing in highly representational media such as photographs and video also is true. ${ }^{67}$ One can understand why the heuristic is developed: if we doubted everything that our eyes were seeing, we would proceed extremely cautiously every moment of our lives. We would move through each moment of our lives as slowly as a private investigator moves when lured into a house of mirrors. Our confidence that what we see in the world before our eyes is really there, really occurring, allows us to move at the speed of modern life-but this heuristic carries over to our viewing of photographs and realistic visual media. Without some additional warning or signal that trickery is occurring, we tend to believe the truth of a depiction simply because we can see it for ourselves. Audiences from lay people to United States Supreme Court justices are ready to say that a photograph or video "quite clearly" speaks for itself; it obviously is the truth. ${ }^{68}$

of the picture is understood to be identical to its content." (endnote omitted)); Jennifer L. Mnookin, The Image of Truth: Photographic Evidence and the Power of Analogy, 10 YALE J.L. \& HUMAN, 1, 2 (1998) ("Seeing a photograph almost functions as a substitute for seeing the real thing." (footnotes omitted)); SEKULA, supra note 60, at 3, 5 ("Put simply, the photograph is seen as a re-presentation of nature itself, as an unmediated copy of the real world. The medium itself is considered transparent. The propositions carried through the medium are unbiased and therefore true."); Christina $O$. Spiesel et al., Law in the Age of Images: The Challenge of Visual Literacy, in CONTEMPORARY ISSLES OF THE SEMIOTICS OF LAW: CULTURAL AND SYMBOLIC ANALYSES OF LAW IN A GLOBAL CONTEXT 231, 237 (Anne Wagner et al. eds., 2005) ("[V]isual stories use a different code for making meaning than do written texts or oral advocacy. . . They are ... rich in emotional appeal, which is deeply tied to the communicative power of imagery. This power stems in part from the impression that visual images are unmediated. They seem to be caused by the reality they depict."); Tushnet, supra note 1, at 691 (Photographs "stop us from thinking" because they are so immediately persuasive.) (quoting Michael Meyer, Recovering Reality: Errol Morris Takes on Abu Ghraib, COlum. JOURnalism Rev., Mar.-Apr. 2008, at 53, 54).

66 There must be creation for copyright to apply, and since 1884, it is undisputed that photographs are copyrightable. See Burrow-Giles Lithographic Co. v. Sarony, 111 U.S. 53, 58 (1884); Michael D. Murray, Post-Myriad Genetics Copyright of Synthetic Biology and Living Media, 10 OKLA. J.L. \& TECH. 71, 77 (2014).

67 See Richard K. Sherwin, A Manifesto for Visual Legal Realism, supra note 4, at 725-26 ("Viewers tend to react to screen images in the same way that they react to reality. Naïve realism apparently is the natural default setting for visual common sense. Subject to our unthinking gaze, which is mostly how we watch, the screen seems to present a window onto reality. We tend to look through the medium rather than at it. Moreover, once we comprehend what we see, that's usually all we need to believe it. In other words, the familiar commonplace that "seeing is believing" is not just idle folk knowledge-not that there is anything "idle" about folk knowledge. Indeed, such knowledge is a major source not only of mental content but also of the cognitive tools most people use most of the time.") (footnotes and internal citations omitted). See also Benforado \&, supra note 63, at 513-14; Lammon, supra note 63, at 241; Ross \& Shestowsky, supra note 63, at 1090.

68 See Scott, 550 U.S. at 378-79, 381-82. In Scott, the Supreme Court reversed the Court of Appeals' decision denying summary judgment because the videotape of the car chase filmed from the pursuing police car "quite clearly" contradicted the version of the facts put forth by the respondent Harris, and accepted by the Court of Appeals; Justice Scalia, writing for the majority, stated that the Court of Appeals "should have viewed the facts in the light depicted by the videotape." 
Therefore, the use of visual images as tools of rhetoric and narrativity in litigation carries with it an enormous responsibility not to abuse the power of images. The power of visual rhetorical devices in legal discourse requires a careful attention to the author's ethical and professional responsibilities not to use the power to confuse, mislead, or overwhelm the reasoning power of the audience. ${ }^{69}$ Visual communication transcends the limits and gaps in verbal language when one's primary goal is to communicate information so that it is received and understood. In rhetorical terms, the goal should be to construct knowledge and understanding in the audience, not to destroy knowledge and confuse comprehension.

\section{B. The Combined Power of Visual Rhetoric and Visual Narrativity}

When visual rhetoric is employed in the context of visual narrativity, two enormous powers are unleashed: the cognitive and persuasive power of visual communication, and the cognitive and persuasive power of narrative. Narrative is powerful because it is nearly essential to our understanding and processing of the world. ${ }^{70}$ Humans cannot help but express their experiences, and those of others, and lessons to be learned from experience, in the form of stories. We are hard-wired to listen to and process stories. We are cognitively dependent on story-forms of communication. Humans receive the information better, process the information better, make sense of the information better, and make decisions about the information better when the information is delivered in the form of a story. It is unsettling to receive information about other people, events, transactions, or occurrences without the framework of a story.

Consider the following communication from your spouse or significant other:

- Delayed 32 minutes at the grocery store this afternoon.

- My bicycle sustained only $\$ 82$ damage (Gill's Bike Shop was open).

* Personal injuries not noteworthy for me and the driver of the car.

- My handlebar camera captured the whole thing.

- No insurance from the driver.

69 Murray, Visual Rhetoric, supra note 11, at 60; Murray, Leaping Language, supra note 11, at 74.

70 Linda L. Berger, The Lady, or the Tiger? A Field Guide to Metaphor and Narrative, 50 WASHBURN L.J. 275, 276 (2011); Sean D. O'Brien \& Kathleen Wayland, Implicit Bias and Capital Decision-Making: Using Narrative to Counter Prejudicial Psychiatric Labels, 43 HOFSTRA L. REV. 751, 765-66 (2015); Anne Moses Stratton, Courtroom Narrative and Findings of Fact: Reconstructing the Past One (Cinder) Block at A Time, 22 QLR 923, 934 (2004); Jonathan K. Van Patten, Storytelling for Lawyers, 57 S.D. L. REV. 239, 242 (2012). 
Is this a satisfactory communication? Do you strongly desire to hear more? Would you like to hear the story of what happened at the grocery store?

So, it is with most, if not all humans-judges, jurors, counsel, clients, and the rest of us. We are dependent on the narrative form for processing facts about the world. It's not just idle curiosity; we cannot properly process such facts without a narrative frame. Given the chance, we will construct our own story to make sense of events and occurrences-it is that important to have a narrative framework for the processing of information. ${ }^{71}$

The analogical and rhetorical use of precedent cases as a source of narrative forms and "stories" in the law is well recognized in American legal method. Precedent cases contain a story, and multiple precedents can contain the same storyline or directly related and analogous storylines. ${ }^{72}$ In American legal method, an attorney often relates her client's situation to one or more of the precedent storylines if the outcome of the stories in the precedents is favorable to the client; by the same token, an attorney will attempt to tell a new story of the client to distinguish one or more precedent cases whose stories do not support a favorable disposition of the client's case.

In the short example above, is it sufficiently useful to simply mention that "My handlebar camera captured the whole thing"? What if the person had texted the following clips from the helmet camera: ${ }^{73}$

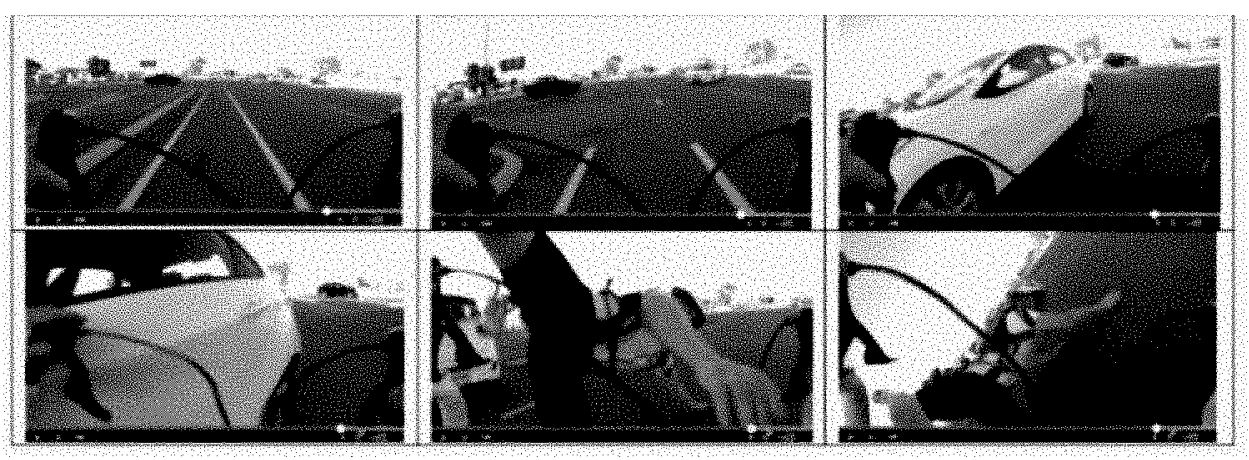

I added no words, but the story of the situation is much more obvious in the version with the image compared to the verbal form, "My handlebar camera captured the whole thing." The emotional appeal of the image is

71 See sources cited in note 69, supra.

72 DeSanctis, supra note 14, at 150-51; Paskey, supra note 14, at 52-53.

73 Michael D. Murray, Sequence of frames from a video recording of a bicycle-automobile collision taken from the perspective of a handlebar camera, derived from the video, Car v. Cyclist, available at https://www.youtube.com /watch?v=ILpDx9MZ6 Tg. 
obvious, too, whether you are the spouse or significant other, or a bicycle rider, or even one who drives a car all the time but recognizes the "Oh my!" nature of these images.

The audience's hard wiring toward processing facts through stories, coupled with the power of visual images to communicate effectively at the speed of the emotional, reptilian brain, reveals the mischief that might potentially be wrought from disingenuous or misleading framing of the case through visual narrativity. Rhetoric used responsibly and ethically builds knowledge and understanding in the audience by constructing reality-the actual reality of the world. Rhetoric should not construct an alternative, fanciful reality.

What are the following cases about? Do the pictures shown on the following page tell the story or create a story?

The stories that go with each photograph are there for the taking. The audience has a choice. If the attorneys on both sides of the case are skilled in visual rhetoric and narrativity, they will present the jury with two plausible narratives; however, only one can be the truth, or at least "more true" than the other. If counsel chooses to use visual rhetorical devices,

7484 S.E.2d 516 (Va. 1954).

75 Image depicting two male friends who appear to be very drunk, derived from photograph available at http://www.miaminewtimes.com/arts/free-shots-cheap-drinks-and-debauchery-inside-the-world-of-organized-pub-crawls6515023.

76 Photograph depicting two executives who are conducting business in a bar, derived from a promotional photograph of Jon Hamm and John Slattery in Mad Men, Copyright (c) 2010-2016 AMC Network Entertainment LLC, available at http://gotham-magazine.com/get/files/image/migration /2297_content_DD-Drinking-7.jpg.

77 Liebeck v. McDonald's Restaurants, P.T.S., Inc., No. CV-93-02419, 1995 WL 360309 (N.M. Dist. Aug. 18, 1994) vacated sub nom. Liebeck v. Restaurants, 1994 WL 16777704 (N.M. Dist. Nov. 28, 1994).

78 Photograph depicting a person holding a cup of coffee between her thighs, derived from photograph available at http://odditymall.com/includes/content/lap-mug-a-coffee-mug-you-can-set-on-your-lap-0.jpg.

79 Image depicting a person with burns from something that had been poured over his chest, derived from photograph (c) 2014 N.Y. Daily News, available at http://www.nydailynews.com/new-york/brooklyn/brooklyn-man-sue-mcdonald-shophot-tea-court-article-1.1993603.

80 Walker v. City of Birmingham, 388 U.S. 307 (1967), and Shuttlesworth v. City of Birmingham, 394 U.S. 147 (1969), both arose out of the same series of events: a black protest march through Birmingham that received violent suppressive opposition from public-safety chief Bull O'Connor of Birmingham. The march produced several arrests, including that of the Reverend Dr. Martin Luther King Jr., who wrote his famous “Letter from Birmingham Jail” while incarcerated in the aftermath of these protests. The two opinions report the same facts, but with narrativity that tells two different versions of the story. Strangely enough, the author of the two opinions is the same: Justice Potter Stewart. Perhaps in the two years between Walker and Shuttlesworth his thinking on the matter had evolved.

81 Image depicting the Good Friday Protest March in Birmingham and the orderly conduct of the crowd, the subject of the cases Walker, 388 U.S. 307, and Shuttlesworth, 394 U.S. 147, derived from the original photograph by Horace Cort, (c) 1963 AP Photo \& Horace Cort (April 12, 1963), available at http://qz.com/328913/martin-luther-king-jr-s-1963-letter-from-birmingham-jail-remains-relevant-today/.

82 Image Depicting the Good Friday Protest March in Birmingham with certain protestors spilling out from the sidewalk, the subject of the cases Walker, 388 U.S. 307, and Shuttlesworth, 394 U.S. 147; derived from the original photo, (c) 1963 Library of Congress, Prints and Photographs Div., NYWT\&S Collection, available at http:/www-tc.pbs.org/wgbh/amex/eyesontheprize/story/images/07_c_04.jpg. 
Lucy v. Zehmer ${ }^{74}$ - Contracting while drunk?

$\begin{array}{lll}\text { The visual: } & \begin{array}{l}\text { What story does it tell? } \\ \text { Two guys got very drunk; } \\ \text { when they sobered up it } \\ \text { appeared they had written } \\ \text { up a joke contract } \\ \text { in all the silliness. }\end{array} & \begin{array}{l}\text { Outcome: } \\ \text { No contract was formed; } \\ \text { no transfer of land. }\end{array} \\ & & \end{array}$

\section{Coffee Spill Case-e.g., Liebeck v. McDonalds ${ }^{77}$}

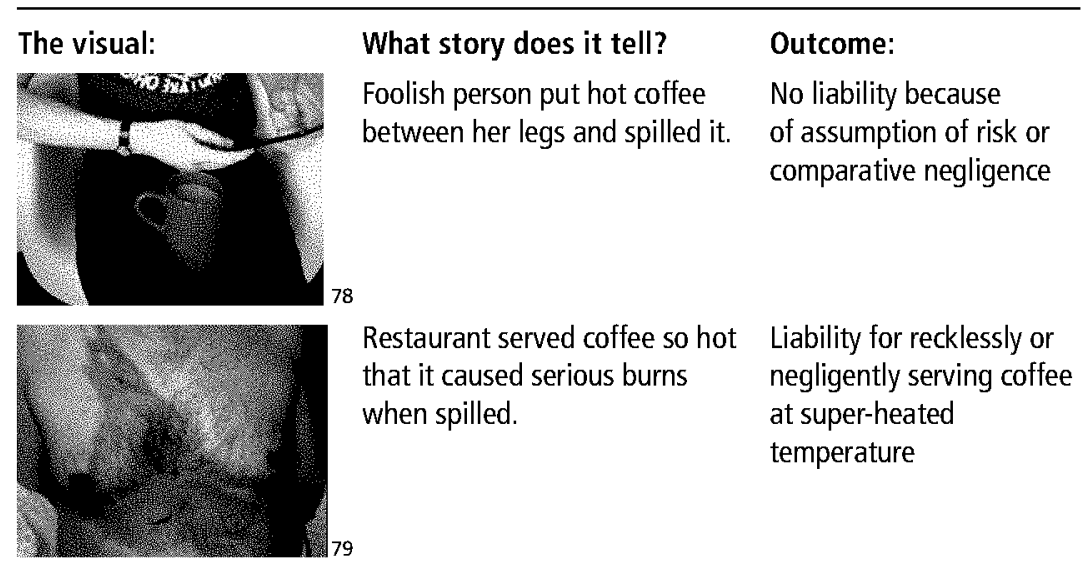

\section{Walker or Shuttlesworth ${ }^{80}$-Which march occurred?}

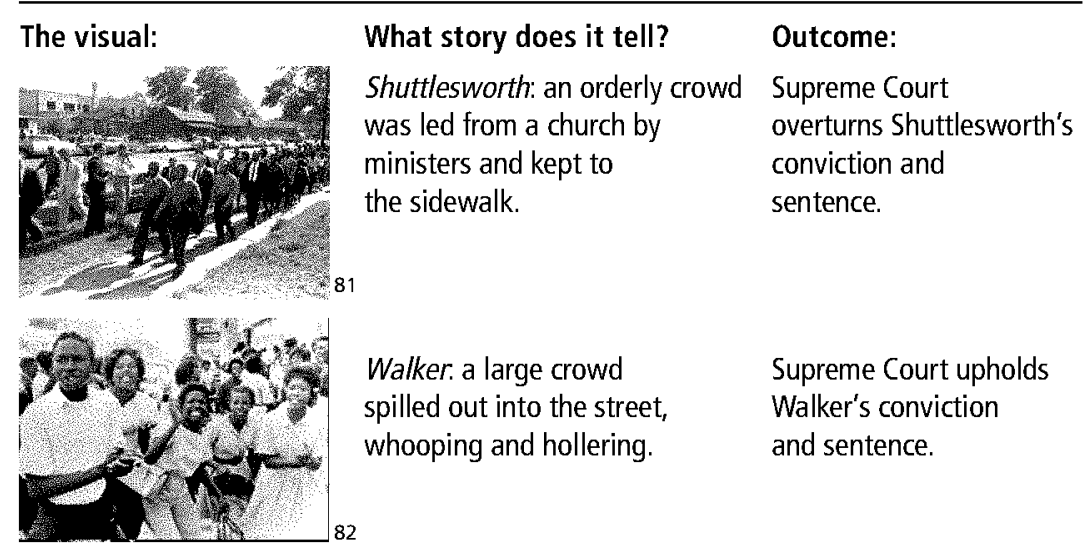


and the other side does not, the counsel using the images at least must make sure their images do not lie about the matters depicted. The opponent may be making the larger professional and tactical error not to try present a counterargument with visuals of her own, given that the biases of naïve realism or cognitive illiberalism will make it very difficult to overthrow the audiences' acceptance of the message communicated in the one visual when it does not have a second visual to compare it to.

The next section explores several recent examples of the rhetorical use of visual images in cases to tell a story of the case, the client, and sometimes of the law. The point of this exploration is to examine the ethical choices made by counsel, and to assess the probable effectiveness of the use of the visuals in the context of the case and the rhetorical situation $^{83}$ it presented for the counsel.

\section{Ethical Lessons from Recent Efforts to use Visual Rhetoric in Briefs}

Questions concerning the ethical and professional responsibilities of attorneys are brought to the fore by several instances of legal communication employing a graphical or audiovisual storytelling device within the context of a work of legal rhetoric. The graphical displays in the cases that follow were not offered as or intended to be proof of a disputed fact in the cases ${ }^{84}$ instead, the primary thrust of the use of visual devices was to communicate a point of argument, to persuade and win the adherence of the audience to the speaker's position.

\section{A. The Cartoon Brief}

One of the most eye-catching of the recent examples of visual rhetoric in legal briefs may be the work of an attorney who filed an amicus curiae brief in the United States Court of Appeals for the Second Circuit in the case, United States 1 . Apple, Inc., ${ }^{85}$ in the form of a five-page cartoon. ${ }^{86} \mathrm{It}$ is telling in that the cartoon novelette presented the story of the amicus author's opposition to the government's action in the case in a sequential

83 See Lloyd F. Bitzer, The Rhetorical Situation, 1 PHIL. \& RHETORIC 1, 6-8 (1968) (defining a rhetorical situation as one requiring choices in communication or argumentation).

84 The dashboard-camera videos in Scott and Reed-Veal ex rel. Bland, supra notes 21-22, were (or in the case of Bland, are likely to be) used for several purposes, one of which may be proof of a disputed, mixed question of law and fact regarding the actions of the patrol officers in the cases. As noted above, I will be focusing on their use or potential use as rhetorical devices.

85 Brief of Bob Kohn, Amicus Curiae, Lnited States v. Apple, Inc., 889 F. Supp. 2d 623 (S.D.N.Y. 2012) (No. 12-cv-2826 (DLC)) (available via his website at http://media.wix.com/ugd/c526cc_439cb9e2d97049c38c04d5b9b43bf361.pdf). 
narrative format, and the author purported to file it as a replacement for a twenty-five-page amicus curiae brief that had earlier been rejected by the court for exceeding the court rules' page limit. ${ }^{87}$
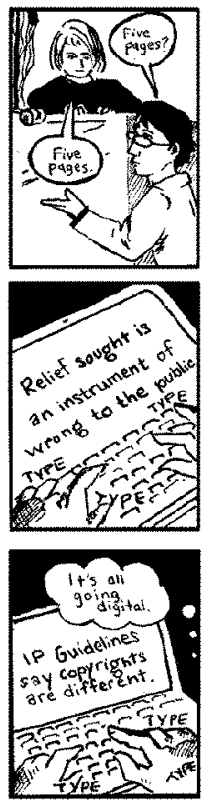
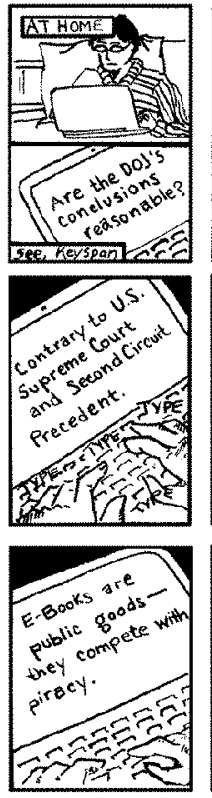
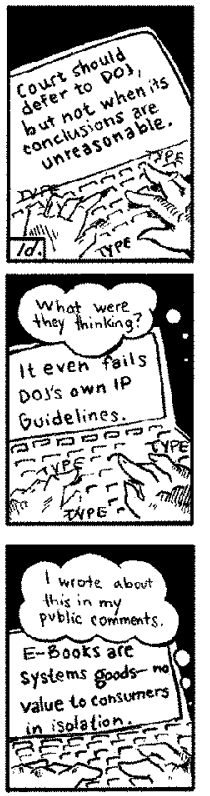
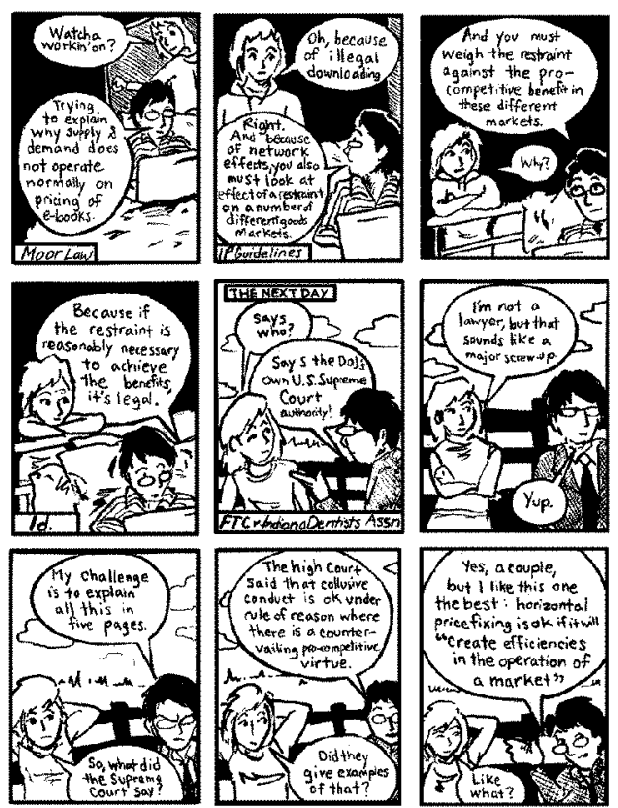
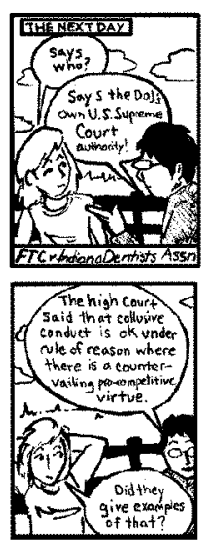
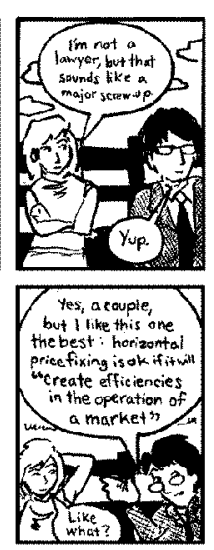

It's noteworthy that the author-attorney included so much text; the brief really is a short verbal summary of the highlights of the argument delivered through a cartoon medium, rather than an argument communicated through visual rhetorical means. Compare the following example, ${ }^{88}$ which uses sequential storytelling with an overwhelming pictorial, rather than verbal, rhetorical message, to assert that the arguments raised against wind energy are trivial in comparison to the arguments against nuclear, oil, and coal energy.

It appears that in the comic brief, the attorney, Bob Kohn, was protesting and expressing his irritation with the court's requirement rather than trying to improve the delivery of his arguments against the DOJ's position in the case. The cartoon form was not

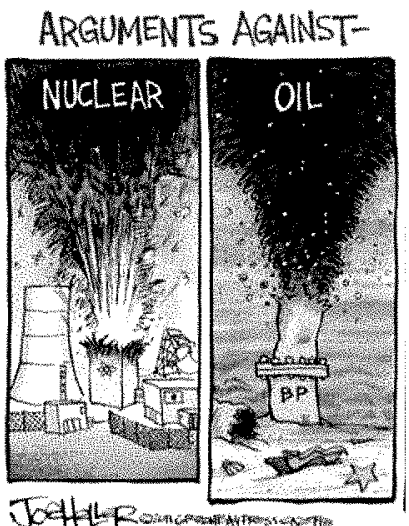

87 Id.

88 Image of visual argument against wind power, excerpted from Cartoon $₫ 2011$ by Joe Heller, Arguments Against Wind Power, http://en.paperblog.com/arguments-against-wind-power-cartoon-says-it-all-223660/ (2011), depicted to demonstrate visual rhetoric relying primarily on images, not words. 
chosen because the form itself allowed superior communication of the highlights of the argument through symbolic imagery or depiction of the circumstances discussed and alluded to in the brief-the unreasonableness and unfairness of applying a simple supply and demand theory to the pricing of ebooks. The characters in the cartoon-the author, we presume, and a bright young woman companion-are just mouthpieces used to parrot the bullet points of the actual amicus brief. There is nothing new or illuminating about the substance of the argument when the author is shown typing it on a laptop while in bed (except perhaps a low-level pathos appeal for the poor guy who has to work late into the evening writing amicus briefs). The cartoon brief even cites legal authority in cartoon narration boxes. In sum, the cartoon seems more about the attorney's desire to poke the court in the eye rather than to achieve superior communication of the substance of the argument.

When evaluated on Steve Johansen's and Ruth Anne Robbins' rubric for determining when to employ visual rhetorical devices in legal contexts, ${ }^{89}$ the Kohn Cartoon Brief does not fare well:

Is the idea of the visual On the usefulness continuum between Decorative Works effective at enhancing the that are extraneous to the analysis, and Transformative reader's comprehension Works that are highly effective at communicating the of the analysis? analysis, the Kohn Cartoon Brief comes across as highly decorative. The visuals are unconnected to the message of the brief itself. The characters of the cartoon-Kohn and a female companion-are mere mouthpieces for an intensely verbal, not visual, argument. The cartoon itself does not effectively convey the legal analysis, only the verbal content does, nor does the visual contribute to the overall theory of the case.

Does the visual improve the document's overall design?

Does the visual meet professionalism norms?

In or out? The verdict. Kohn would have been better off filing a five-page abstract of his twenty-five-page amicus brief rather than showing off with his cartoon brief. The verdict is "out." 


\section{B.Side-by-Side Demonstration in Apple v. Samsung}

In another case involving Apple, Inc., Apple made a completely visual argument using only photographs to show the "before and after" products of its sometime partner, all-the-time competitor, Samsung. The lawsuit alleged claims of trademark, trade dress, and patent infringement, and part of the claims were that Samsung had copied the look, the feel, the operation, and the functioning of the iPhone as nearly as possible. The "before and after" exhibits attempt to show the copying. The "before and after" time frame refers to the introduction of Apple's iPhone. ${ }^{91}$
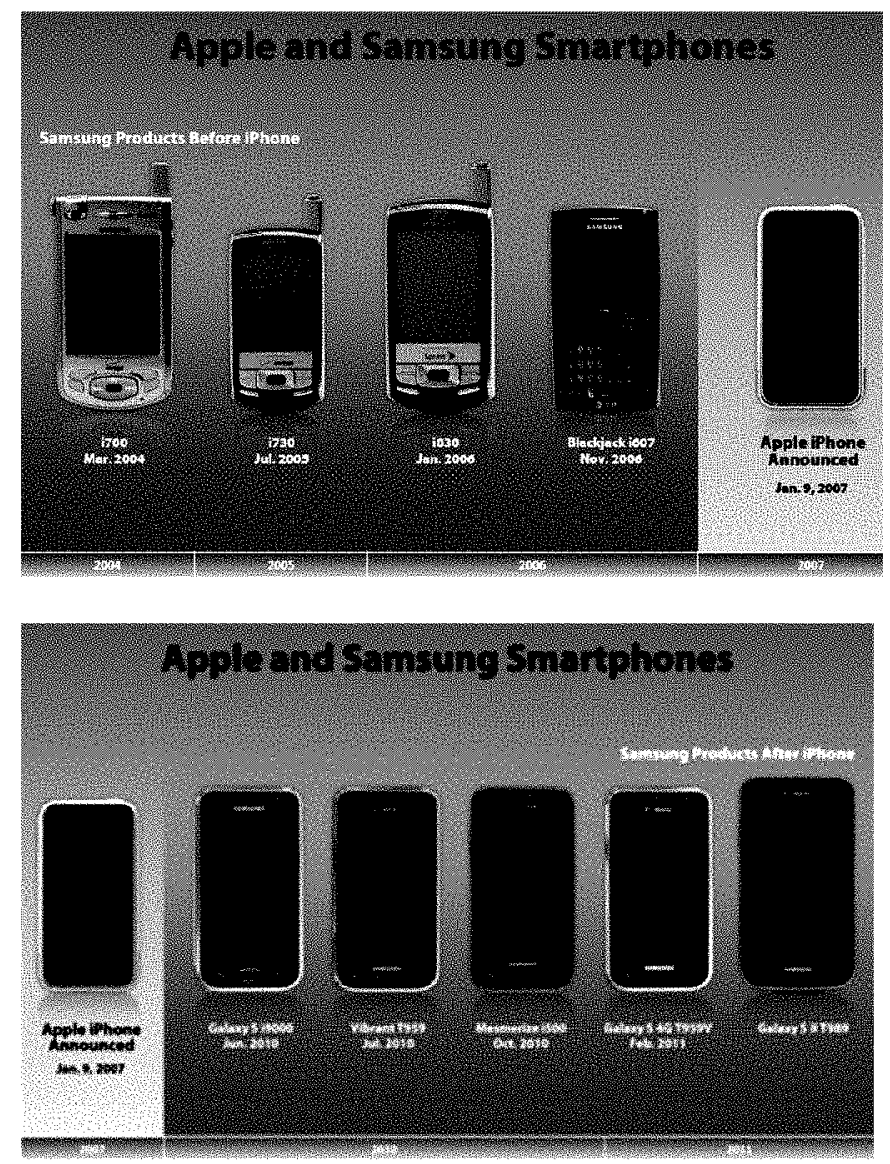

89 Steve Johansen \& Ruth Anne Robbins, Art-iculating the Analysis: Systemizing the Decision to Use Visuals as Legal Reasoning, 20 LEGAL WRITING 57, 86-93 (2015). Johansen and Robbins evaluated the Kohn Cartoon Brief, and found that the use was unpersuasive in its execution and unprofessional in its tone because it appeared that the litigant was mocking the court's imposition of a five-page limit on the litigant's amicus brief. $I d$. at $65 \& \mathrm{n} .30$.

$90 \mathrm{Id}$. at $65 \& \mathrm{n} .30$.

91 Apple Trial Exhibits used in Apple, Inc. v. Samsung Electronics Co., Ltd., No. 12-CV-00630-LHK (N.D. Cal. Apr. 15, 2011), available at http://arstechnica.com/tech-policy/2012/08/apples-case-that-samsung-copied-the-iphone-and-ipad-inpictures/. 
Apple did a good job with the visuals: the Samsung products shown as "before" do not look at all like an iPhone, but the products "after" look exactly like an iPhone. Apple's visual argument, however, incorporated the logical fallacy of the undistributed middle. Apple's depictions make the implicit claim that "Before the iPhone, all of Samsung's phones did not resemble the iPhone; after the iPhone, all of Samsung's phones looked just like the iPhone." The fallacy is the implicit suggestion of "all" phones. Samsung responded to the exhibit by pointing out Apple's selective construction of the depictions above that created the implicit message of "all of Samsung's phones..." and showed a rebuttal exhibit displaying the full range of "Samsung products" before and after the iPhone. ${ }^{92}$

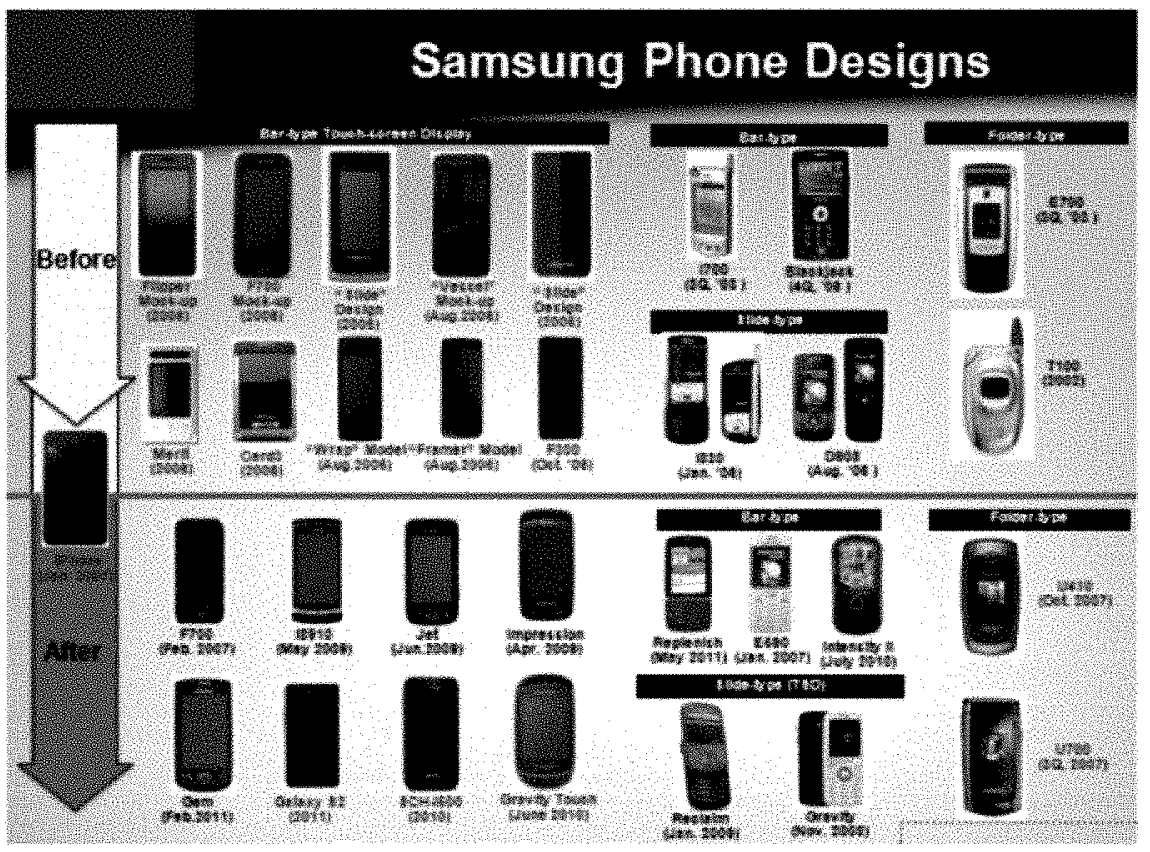

Samsung showed that lots of its phones before the iPhone resembled the iPhone, and lots of phones after the iPhone did not resemble the iPhone. Neither of the sets of exhibits for both sides fully addresses the point for which the exhibits were offered: Did Samsung copy the iPhone in any of its phones? Samsung was willing to admit that some phones created after the iPhone closely resemble the iPhone most likely because it enjoyed striking a blow against Apple's ethos by showing the mismatches before and after in Apple's exhibits.

On Johansen's and Robbins' rubric: 


\begin{abstract}
Is the idea of the visual On the usefulness continuum between Decorative Works effective at enhancing the that are extraneous to the analysis, and Transformative reader's comprehension of the analysis?

Works that are highly effective at communicating the analysis, both sets of exhibits are transformative and effective at making their point. In Apple's case, it is clear that Samsung did make post-iPhone phones that highly resemble the iPhone; in Samsung's case, it is equally obvious that the iPhone look-alikes were only a few of the phones that it made after the iPhone's introduction. The visuals are directly connected to the message of the brief regarding allegations of copying.
\end{abstract}

Does the visual improve the document's overall design?

\section{Does the visual meet professionalism norms?}

In or out? The verdict.
When arguing that certain items look like others, there is hardly ever a better way to make this point than by showing the items side-by-side. The side-by-side presentation allows superior communication of the argument.

There is nothing unprofessional about the exhibits used by Apple and Samsung. I have mentioned that Samsung apparently reacted to a logical fallacy of the argument that Apple appeared to be asserting in its exhibits-namely, that "all" of Samsung's phones were copies of the iPhone after the iPhone's introduction. But this strategy itself required Samsung to admit (with visual demonstration) that in fact it did make several phones that looked quite a bit like the iPhone after the iPhone's introduction, just not all of its phones. This is perhaps a limitation of the arguments on each side, but one that does not suggest that it was unethical to use visuals to make the points each side decided to try to make.

The decision whether to use the visuals is a strategic decision for both sides. The exhibits prepared did make the intended arguments much more effectively than if Apple had simply argued verbally that several Samsung phones looked a lot like the iPhone after the introduction of the iPhone, and Samsung replied verbally, not all of them. Showing these facts improved the communication. But it opened up each party to counterarguments that were also supported by the visual demonstrations.

We can debate who got the better of these dueling exhibits, but the point is the one Richard Avedon made: both sets of exhibits are accurate, but neither one tells "the truth," or, more aptly stated, "Every photograph depicts reality, but none of them is the sole, true depiction of that reality."93

The visual exhibits are the arguments of counsel. Neither set reveals the truth of what we are trying to determine in the case: Did Samsung copy Apple's phone design? But neither exhibit is unprofessional or

93 Paraphrase of Richard Avedon, "All photographs are accurate. None of them is the truth." Martinez-Conde \& Macknik, supra note 25. 
unethical: neither exhibit lied, or obfuscated, or misrepresented the truth. Each exhibit told a true story, but of course each highlighted one small aspect of the story that was advantageous to the client's position, while still opening up the client to counterarguments-Apple's having to admit that a lot of Samsung's phones looked like the iPhone before the iPhone (and a lot didn't look like the iPhone before and after the iPhone), and Samsung's having to admit that some of its phones did look a whole lot like the iPhone after the introduction of the iPhone. The visuals were better at telling the specific part of the story the client wanted to tell than verbal means would have been. Therefore, this example represents a strategic decision as to whether the upside of these visuals exceeds the downside.

\section{The Maverick "One Image" Summary-Judgment Brief}

Another noteworthy effort to argue without words is the short, summary-judgment brief filed by the Dallas Mavericks in the Hillwood Investment Properties v. Radical Mavericks Management case, ${ }^{94}$ sometimes referred to as Mark Cuban's "f- you brief."

The whole point of the summary-judgment motion was to make ridiculous plaintiffs' assertion that Mark Cuban had made questionable business and financial decisions concerning the Mavericks and had caused the value of the Mavericks to decline over the course of his control, compared to the time when the plaintiff, Hillwood, had controlled the franchise. The brief is little more than a single photograph that shows a victorious Mavericks team celebrating their league championship in 2011 ("Photograph Brief"). The argument is, "How can Mark Cuban have done anything wrong?! We won a league championship!" It is possible there were other motives at work, perhaps a hope that the state district-court judge in Dallas would be a Maverick's fan, or at least happy and proud that the team won a championship under Cuban's management?

The story of the Photograph Brief, however, was denied an ending fit for a legal learning point: the Mavericks' attorneys withdrew the Photograph Brief and replaced it with a traditional, completely verbal, amended summary-judgment brief; the trial court granted summary judgment to the Mavericks, and the judgment was affirmed. ${ }^{96}$

94 No. 10-05639, 2011 WL 2533342 (Tex. Dist. Ct. 2010).

95 See images at https://html1-f.scribdassets.com/7e8b5lnh8g10it4f/images/1-4c668ead2b.jpg, or http://deadspin.com 15814499/the-brilliant-legal-mind-behind-mark-cubans-fuck-you-brief. The brief is four pages long, with one full page taken up only by the law firm's signature block and certificate of service.

96 See Hillwood Investment Properties v. Radical Mavericks Management, LLC., No. 05-11-01470-CV, 2014 WL 4294968 (Texas App. Aug. 21, 2014), available at http://highline.huffingtonpost.com/miracleindustry/americas-most-admiredlawbreaker/assets/documents/9/Melsheimer-Mavericks-motion.pdf. 

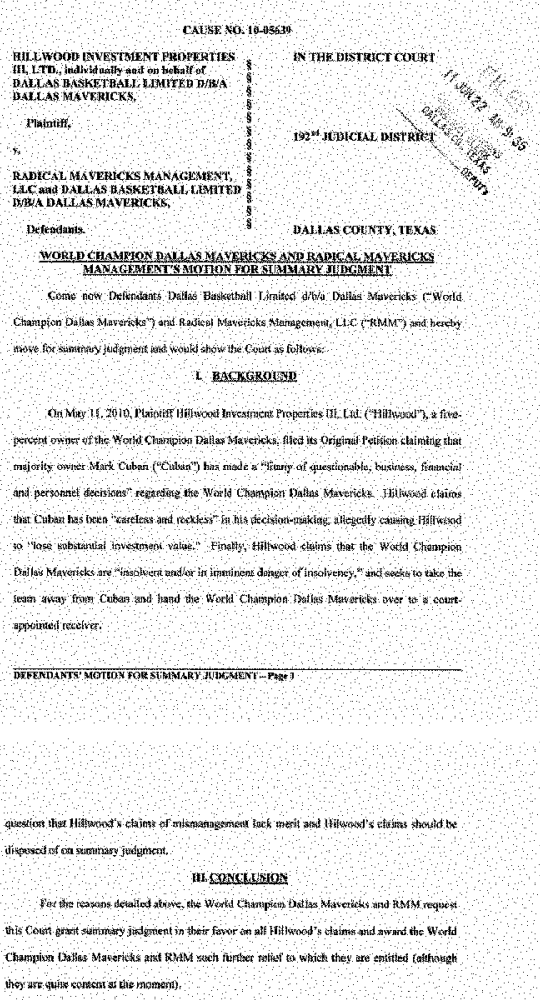

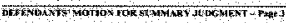

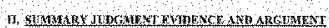

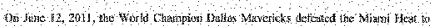

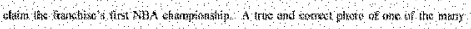

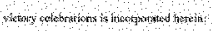

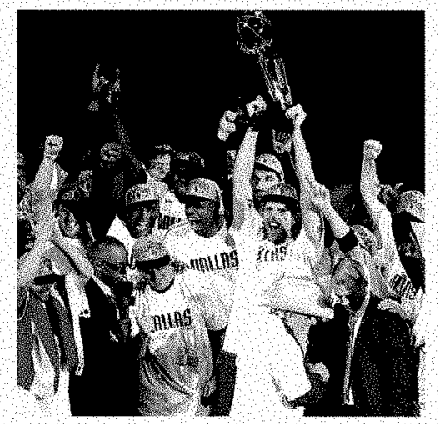

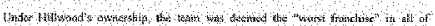

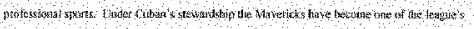

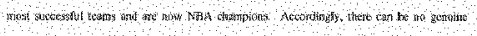

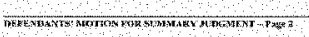

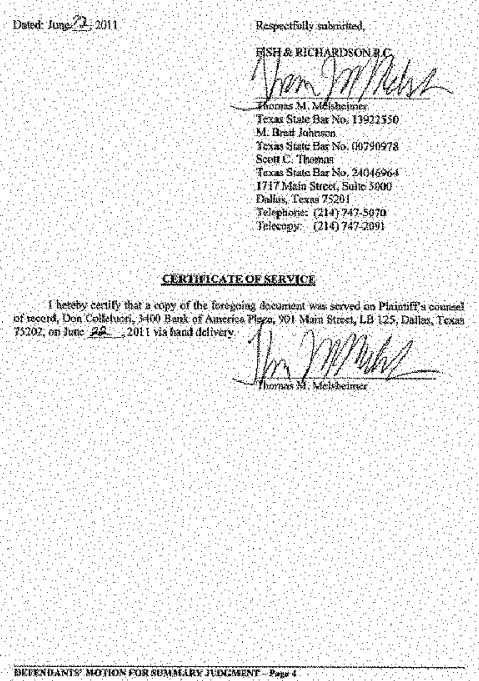

The Photograph Brief raises a separate issue of professional responsibility: instead of addressing the merits of the case and the assertions of the plaintiff's complaint, this summary-judgment brief makes a grand gesture to ask the court to forget the details, forget the specifics, forget the various legal theories about cash flow, net worth, profitability, and proper management of a professional sports team, and focus only on one thing: "Under Mark Cuban, the Mavericks won a championship. 'Nuff said. Don't 
sweat the details, judge." This strains the professional responsibility of the defendants' counsel not to mislead the court as to the potential facts in dispute and the matters at issue in the case. The Photograph Brief can be interpreted to mean, "Nothing else is relevant, nothing else is in dispute or at issue in this case, and defendants are entitled to summary judgment simply because the team won a championship under defendant's management."

On Johansen's and Robbins' rubric:

Is the idea of the visual
effective at enhancing the
reader's comprehension of the analysis?

Does the visual improve the document's overall design?

Does the visual meet professionalism norms?

In or out? The verdict.
On the usefulness continuum between Decorative Works that are extraneous to the analysis, and Transformative Works that are highly effective at communicating the analysis, the Championship Photograph is the most blatant and troubling form of decoration: it is a cover-up, an obvious distraction. It has nothing to do with enhancing the reader's comprehension of the analysis. It wants the reader to forget that there is any analysis to perform-"Just remember, Mark Cuban delivered a championship, and vote for Cuban!"

The photograph was the brief, so it is difficult to question whether it improved on the design when it was the design. The photograph is memorable as a spectacle, although not as a great work of advocacy.

It is highly questionable to abandon all reason and suggest through visual rhetoric that the judge should ignore all of the facts and issues raised by the opponents and focus only on one fact, that the Cuban ownership group delivered a championship. It is an irresponsible appeal purely to pathos and emotion that encourages the court to follow counsel's lead and decide the case in defendant's favor regardless of the facts, the law, and the application of the law to the facts. Defendants' counsel most likely realized this when they withdrew the Photograph Brief and filed a substantive brief using traditional verbal legal discourse.

By itself, the Championship Photograph should not be the sole medium to make a complicated argument on business law and fiduciary duties. The visual could have been used for a more strategic purpose to build a strong pathos reaction in the audience, and using the photograph as an anchor for substantive arguments regarding the proper management of the team-as proved in part by the fact that the owners managed to deliver a championship.

As suggested in the last panel of the table above, the defendants' point regarding the importance of the Maverick's championship run in 2011 could have been made more effectively by using the championship 
photograph as a framing device, up front, in the introduction of the brief. I have reconstructed the beginning of the brief to reflect this kind of use: ${ }^{97}$

\section{Defendants' Motion for Summary Judgment}

Come now Defendants Dallas Basketball Limited d/b/a Dallas Mavericks ("Dallas Mavericks") and Radical Mavericks Management, LLC ("Radical Mavericks") (collectively, "Defendants") and hereby move for summary judgment and would show the Court as follows:"

\section{[I. INTRODUCTION]}

[On June 12, 2011, the Dallas Mavericks defeated the Miami Heat to win the franchise's first World Championship.]

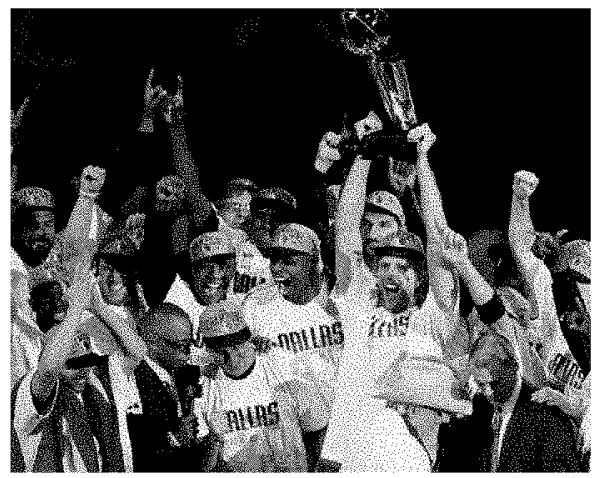

[The best way to increase the value of an NBA franchise is to win an NBA championship and create a sustained period of winning. Cuban Affidavit at ๆ 7.] Since 2000, Cuban's and Radical Mavericks' strategies and leadership have succeeded, and turned the Dallas Mavericks franchise from a loser to a winner. The Mavericks have won 50 or more regular season games (out of 82) for eleven straight years. Id. at 113 . As a result, the Dallas Mavericks have the NBA's longest sell-out streak at over 400 games. Id. at $\uparrow 14$.

Plaintiff Hillwood Investment Properties III, Ltd. ("Hillwood" or "Plaintiff") voluntarily dismissed over half of its claims including all claims for damages. Remaining in this case are fatally[]flawed claims for breach of fiduciary duty, receivership, an accounting, and attorney's fees. Defendants are entitled to summary judgment on each of Plaintiff's remaining claims for the reasons set forth below: ...

The primary ethical and professional problem with the Photograph Brief was that it asked the court to forget the details, forget the specifics, forget the various legal theories and potentially disputed facts about cash flow, net worth, profitability, and proper management of a professional sports team, and focus only on one thing: "Under Mark Cuban, the Mavericks won a championship." This strains the professional responsibility of the defendants' counsel because the Photograph Brief suggests

97 The example I have created redacts the bulk of the defendants' modified motion and modifies its organization. Defs' Am. Mot. for Summ. J., Hillwood Investment Props. III v. Radical Mavericks Mgt., No. 10-05639, 2011 WL 4862623 (Tex. Dist. Ct., Oct 3,2011 ). The actual amended motion does not use the photograph shown here. 
that nothing else in the case is relevant, nothing else is in dispute or at issue in the case, and that the defendants are entitled to summary judgment simply because the team won a championship under defendants' management.

The revised example corrects this ethical and professional problem and focuses the court's attention on an important part of the narrativethe success of the team under Cuban's and Radical Mavericks' leadership, part of which is the championship; but the brief no longer suggests that this last fact is the only fact that matters. The revised brief does not attempt to distract the court or persuade the court to ignore potentially relevant claims and defenses and potentially disputed issues of relevant fact. The photograph is a powerful rhetorical device, but when used a framing device to focus attention, and not as a cudgel to cause concussion and amnesia in the court, it fulfills the professional responsibility of counsel to assist the court in making a proper determination of the case.

\section{Van Orden: Visuals Affirming a Common Argument}

A more skillful use of visuals as argument is seen in the Ethics and Public Policy Center's amicus curiae brief submitted in Van Orden $v$. Perry. ${ }^{98}$ The subject matter of the Supreme Court case is the display of a monumental sculpture of the Ten Commandments on government property in Texas, and whether the display violated the Establishment Clause of the U.S. Const. amend. I.99 Rick Perry, the Governor of Texas, is the named respondent. Instead of simply arguing (in words) that there are lots of images of the Ten Commandments displayed on and in all sorts of government buildings-including the United States Supreme Court-the Ethics and Public Policy Center decided to show that this is so. On the following page are captured images from the amicus brief. ${ }^{100}$

The imagery used in this amicus brief supports the argument. The amicus curiae is not attempting to make a rhetorical point outside of the content and substance of the legal issues in the case. The visuals bolster the verbal argument that the image of the Ten Commandments is used pervasively on and in government and court buildings as part of our history, culture, and heritage. The images frame the argument in a nonoffensive manner by indicating that the Ten Commandments are

$98 \mathrm{Br}$. for the Ethics \& Public Policy Center as Amicus Curiae in Support of Respt's, Van Orden, 545 U.S. 677, available at http://www.eppc.org/docLib/20050204_decalogue.pdf (last visited Mar. 16, 2016).

99 See id.; see also Van Orden, 545 U.S. 677.

$100 \mathrm{Br}$, for the Ethics \& Public Policy Center as Amicus Curiae in Support of Respt's, Van Orden, 545 U.S. 677, available at http://eppc.org/docLib/20050204_decalogue.pdf. 
commonly placed on important government structures in including the very doors of the United States Supreme Court (thus arguing that Texas is not acting out of the ordinary in its display), and that the presence of the Ten Commandments motif in these high government places has not worked any mischief, and certainly not the kind of mischief one might fear from an establishment of religion. The attorneys for the amicus curiae in

And the millowe of visitors to the National Archives pass ower browe plaque inseribed with the Decaloge ablets:

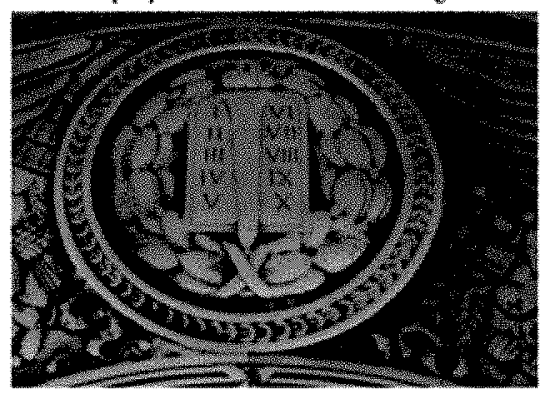

Indeod, Dacalogue imagery proces the home of all three Branches of our federal government. Moses and the Ten Commandments aperat on both the south fricke of the counrooun in which this Coun sits and the pediment of the Coun" bulding:
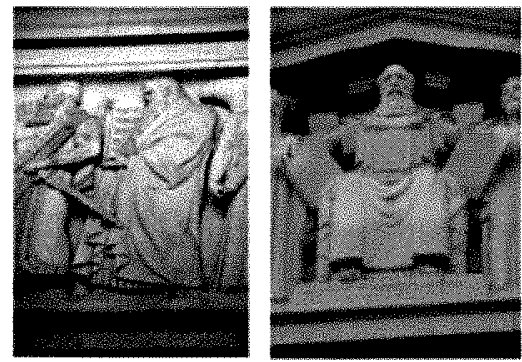

references to religious history from American public buildinges. An order requiting the removal of the Ten Command menis monument from the grounds of the Texas siatehouse would be bat a sliver remeved from a directive to remove the Dowalogue entern from the doors of this Conte

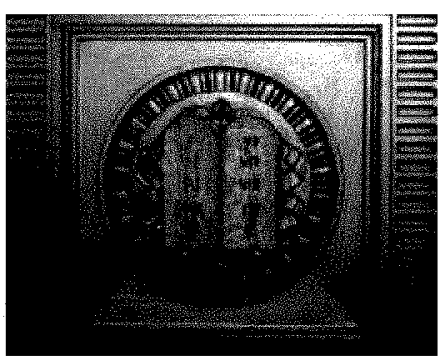

A holding that the First Amendment prostribes the display of the Ten Commandments on public property could-and, if petitiones and the ACLU have their way. would-lead to the desecration of every pubitc butiding that contains scolipture, frieze, engraving ot other representation of the fumdamental law. 
Van Orden are not using visual devices to be cheeky or impudent, as it appears was a large part of the motivation of the attorneys in the United States v. Apple, Inc., and the Dallas Mavericks case.

On Johansen and Robbin's rubric:

Is the idea of the visual The amicus sought to make an argument that the Ten effective at enhancing the Commandments are a common fixture of many important reader's comprehension of the analysis? government buildings, including the U.S. Supreme Court. By showing the actual uses of the Commandments motif on these buildings, counsel has anchored the argument with a real-world reference and with the cognitive power of visual rhetoric (seeing is believing), the use of visuals is transformative, and it does enhance the comprehension of the argument.

Does the visual improve The visuals are an effective framing device to show that the the document's overall design? Ten Commandments are common fixtures of government structures, and that the presence of the Ten Commandments motif in these high government places has not worked any mischief, and certainly not the kind of mischief one might fear from an establishment of religion. This design is effective and nonoffensive, and thus does improve the overall design of the brief.

Does the visual meet professionalism norms?

The use of the visuals is both ethical and professionally responsible. Counsel has shown by repetition of visual imagery that the Commandments motif is common on important government buildings. Nothing was obfuscated, exaggerated, or misrepresented in this presentation of images. The images directly support the argument that the amicus was trying to make.

In or out? The verdict. The verdict is "in."

The use of the visuals depicting the Ten Commandments motif on many important government buildings was ethical and professional. The Van Orden amicus introduced the visual element of the Ten Commandments as a fixture, part and parcel of the doors and friezes it adorns. Counsel also verbally argued that removal of each of these motifs would be a great insult to the traditions and history of the institutions whose structures bear this motif, and to the traditions and history of the country as a whole. In making this argument, counsel interjected a verbal picture: desecration of every public building that contains a sculpture, frieze, or engraving of the Ten Commandments. The word, desecration, is a powerfully visual term, and well suited for a presentation to the high court whose current members are entirely Jewish or Roman Catholic, ${ }^{101}$

101 Samuel G. Freedman, Among Justices, Considering a Divide Not of Gender or Politics, but of Beliefs, N.Y. TIMES, July 11, 2014, available at http://www.nytimes.com/2014/07/12/us/supreme-court-decisions-in-a-catholic-jewish-context.html?_r=0 (last visited Mar. 16, 2016). 
and all of whom are American. Counsel was content to conjure up the image of desecration with words, and did not use pictures depicting examples of desecration in their brief. If, instead of relying on the verbal picture, counsel had used a visual picture of "desecration," such as the three images below, the analysis might be different:
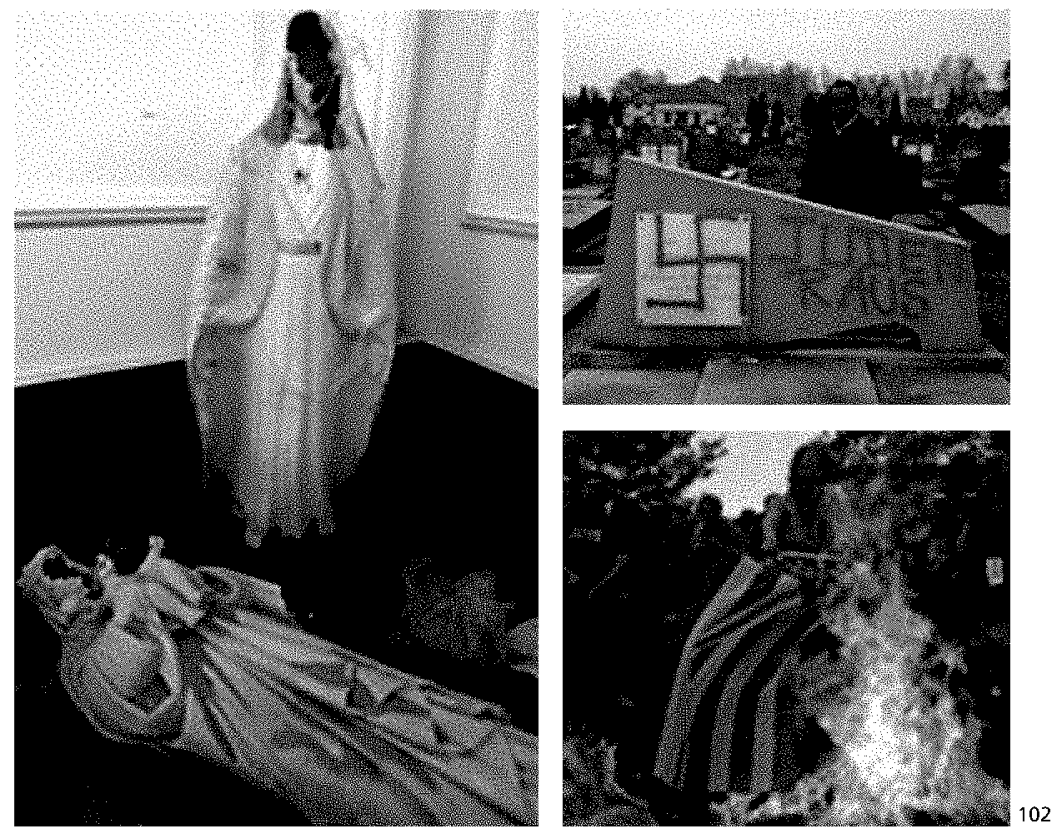

These visualizations of the word, desecration, communicate the concept well, and are loaded with pathos potential. But the use of such images would potentially confuse the issues and the analysis of the case to such a degree that the use would likely be regarded as unprofessional if not unethical. The destruction of sacred objects with religious and historical significance through anger and intolerance was not at issue in Van Orden v. Perry. Therefore, the visualization of this kind of destruction would serve as a pernicious form of "decoration" to distract and confuse the audience, rather than to build knowledge and understanding of the issues

102 Images top to bottom: (1) image of desecrated church in Syria, original photograph @ 2014 by Haitham Moussawi, available at https://www.jihadwatch.org/2014/04/interfaith-outreach-in-syria-islamic-jihadists-desecrate-church-smashicons-and-statues, and at http://pamelageller.com/2014/04/photos-churches-syria-ruins-desecrated-icons-statues -smashed\%E2\%80\%8F\%E2\%80\%8E.html/ (Apr. 1, 2014); (2) image of Desecrated Jewish Graveyard, original photograph (c) 2010 Shlomo Molla, available at http://www.vosizneias.com/47944/2010/01/27/strasbourg-france-20-tombstones-injewish-cemetery-defiled-with-swastikas/; see also Jodendom Online, Increase in Anti-Semitism in EU, http://www.jodendom-online.nl/news.php?view=item\&id=875 (Dec. 16, 2009) (tr. Google); (3) image of United States flag burning, original photograph (c) 2004 Jake Price \& Sipa Press, available at http://www.nbcnews.com/id/8318974/ns/politics/t /house-oks-flag-desecration-amendment/\#.V 1cIWuYrKM9 (June 22, 2005). 
of the case, with the additional motive of persuading the audience to resolve the case in the client's favor.

\section{E. Dashboard Cameras: Scott and Bland}

Dashboard cameras are becoming and should be expected to continue to become a frequent silent or audio-enhanced witness to incidents occurring in front of police cars. Add to this the increased use of body cameras for police officers, and law-enforcement officials and attorneys will find themselves riding a growing wave of potential visual rhetorical subject matter.

Scott v. Harris ${ }^{103}$ provoked an outpouring of discussion on visual rhetoric in general, and the nature of naïve realism in particular. ${ }^{104}$ Scott was an appeal from a personal-injury lawsuit in which the plaintiff was the driver of a car speeding away from the patrolmen engaged in the pursuit of the plaintiff. The patrolmen determined to end the high-speed chase with the plaintiff by bumping the rear of his car in what is described as a "Precision Intervention Technique" (PIT) maneuver. This caused the plaintiff's car to veer off the road, where it overturned and came to a nasty halt in a ditch. Plaintiff suffered severe injuries in the crash and sued the highway patrolman who performed the "PIT maneuver" under a theory that the decision to bump and the execution of the bump itself was made and done recklessly, and constituted an excessive use of force. ${ }^{105}$

The dashboard video was used substantively in the case to aid the argument that, based on the facts of the case, the officer was not reckless nor unreasonable, but in fact acted in an "objectively reasonable" manner in the circumstances. One of the main reasons the case gained fame in the legal academy was that Justice Scalia argued that the video "quite obviously" showed all the facts that were needed to make this determination. In Scalia's view, the video "quite obviously" showed the circumstances to a degree of certainty that allowed the finder of fact to find that the officer's conduct in bumping the back of the claimant's car was objectively reasonable. Other law-trained viewers of the grainy, dark, nighttime footage, taken entirely from the single-camera perspective of the police officer's patrol-car dashboard, argued that the video was not "the truth"; it was simply one recorded perspective on the scene, limited in

103550 U.S. 372.

104 E.g., Kahan et al., supra note 64; Nancy S. Marder, The Court and the Visual: Images and Artifacts in U.S. Supreme Court Opinions, 88 CHL.-KENT L. REV. 331, 360-63 (2013); Porter, supra note 2, at 1754 . The issues concerning naïve realism are discussed further in section IV, infra. 
detail, and limited in what it can tell us about objectively reasonable actions in the circumstances. ${ }^{106}$

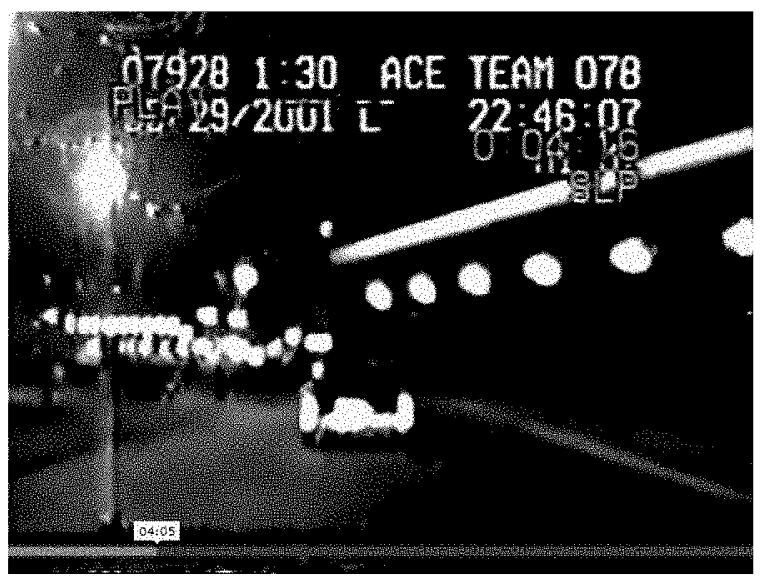

I do not question the use of the Scott video in the presentation of the defendants' case as unethical. It is a recorded perspective on the actual incident that led to the lawsuit, and however limited it might be in its grainy, dark, singular perspective, it does not lie. The fact that the car chase and the "bump" from the police officer is recorded on video is useful in an evidentiary and rhetorical sense to help construct the events of that evening, and build knowledge and understanding in the audience.

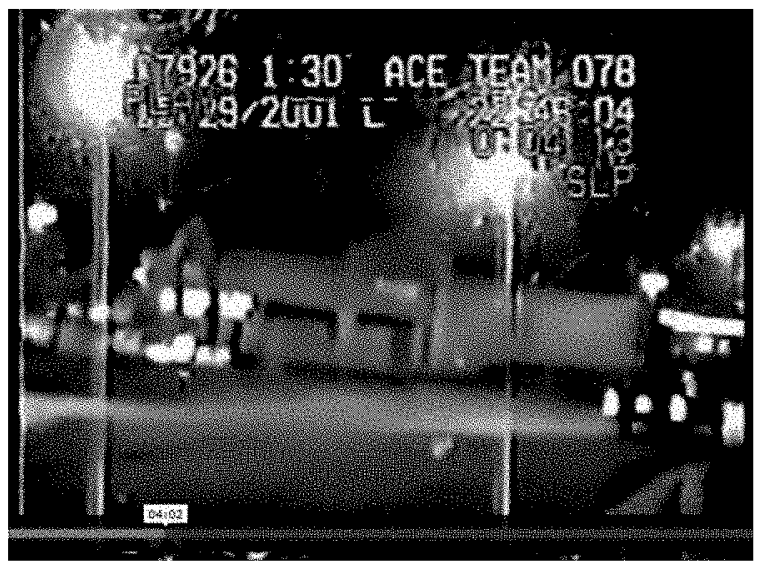

The United States Supreme Court ultimately determined that there was no disputed question of material fact concerning the reasonableness and propriety of the officer's actions, based in large part, if not solely, on 
the basis of the justices' seeing what is shown in the video. ${ }^{107}$ The Supreme Court reversed the Court of Appeals' decision denying summary judgment because the videotape of the car chase filmed from the pursuing police car "quite clearly" contradicted the version of the facts put forth by the respondent Harris, and accepted by the Court of Appeals; Justice Scalia, writing for the majority, stated that the Court of Appeals "should have viewed the facts in the light depicted by the videotape." 108

On Johansen's and Robbins' rubric:

\begin{abstract}
Is the idea of the visual effective at enhancing the reader's comprehension of the analysis?
\end{abstract}

Does the visual improve the document's overall design?

\section{Does the visual meet professionalism norms?}

In or out? The verdict. The verdict is "in." case. available means.
Yes, the video is transformative because it shows a unique recording of the actual events at issue in the suit. Although it is only one perspective on the events, it is a recording that greatly enhances the audience's ability to comprehend the

The video allows counsel to communicate in a manner and at a level that cannot be touched by verbal submissions or even testimony. Therefore, the use of the video drastically improves the arguments submitted by counsel.

The use of the video implicates both ethical and professional questions. First, the counsel for the plaintiff has no ability to produce a visual counternarrative; there is only one recording of the events at issue in the case, and it is the one taken from the perspective of the pursuing officer's patrol car dashcam. Second, counsel for the patrolman should at least consider the effect of naïve realism and cognitive Illiberalism (discussed in section III(A) above) brought to the fore by the use of the one-sided, one-perspective video. However, strategically, the benefits of using a video that shows the actual events leading up to the suit is so advantageous to making the argument that one can hardly fault the attorneys who chose to use the video. Choosing not to use the video when you had it would be subject to greater criticism for not serving the client's interests with the best

Scott should be compared to the police-patrol-car dashboard video in Sandra Bland's case. ${ }^{109}$ Sandra Bland was a Chicago area native who was preparing to take a new job in Texas. She was pulled over for failing to signal a lane change. The officer involved, Brian Encinia, became extremely irritated by Bland's uncooperative attitude, and began to phys- 
ically take charge of her person. After a rough handling, Bland was transported to a county-jail lockup, where she died of an apparent suicide three days after her jailing. ${ }^{110}$

The audiovisual account in the Bland case is that of her traffic stop and arrest, which shows an escalating encounter between a Caucasian patrol officer and a black motorist. After being stopped, ostensibly for failure to signal a lane change, Bland is less than fully cooperative with the demands of the officer, and she verbally questions and challenges his actions continuously in a loud and somewhat abrasive manner. The police officer, Brian Encinia, takes great offence at her failure to automatically comply with his demands to put out her cigarette and get out of the car, and quickly adopts a physically and verbally aggressive attitude with Ms. Bland. After being pulled bodily from her car, Bland verbally abuses the officer with profanity and threats of litigation over the incident. ${ }^{111}$
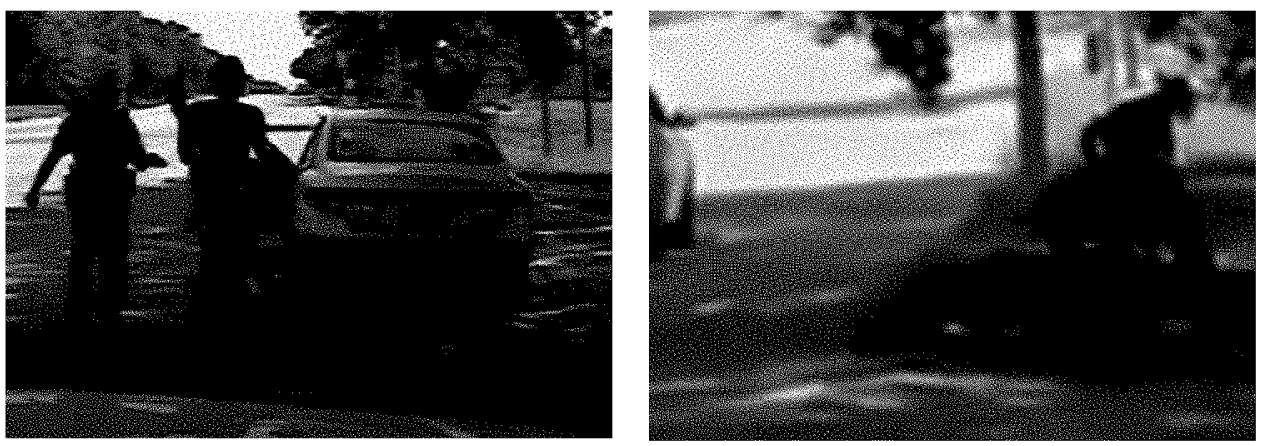

A second video was taken by a bystander, before Officer Encinia ordered the bystander to stop filming and move on. This second video fills in visuals of Bland's handcuffing and suppression on the ground, which were not within the frame of the officer's dashcam video, but were recorded in the audio of the dashcam video. ${ }^{112}$

The dashcam video provides a useful object lesson for users of audiovisual rhetorical devices: first, the Texas Department of Public Safety quickly released a version of the dashcam video, and stated their assurance, in so many words, that "This will clear up everything." In fact the video contributed to the growing doubts and suspicions of many

110 Timeline: What Happened to Sandra Bland, STATESMAN (Jul. 31, 2015), http://www.statesman.com/timeline/sandrabland/.

111 Images on this page are screenshots from the dashcam-video recording of the traffic stop and arrest of Sandra Bland, excerpted from the original video 2015 by Phillip Alan Pyle II, YOUTUBE (July 21, 2015), available at https://www.youtube,com/watch?v=i73P9Qb5Ig4.

112 Id., https://www.youtube.com/watch?v=i73P9Qb5Jg4. 
observers because the video released had been altered. Sections of recorded footage had been edited out. Casual observers could see that cars appeared in the frame only to disappear a moment later, as shown in the following two images: ${ }^{113}$

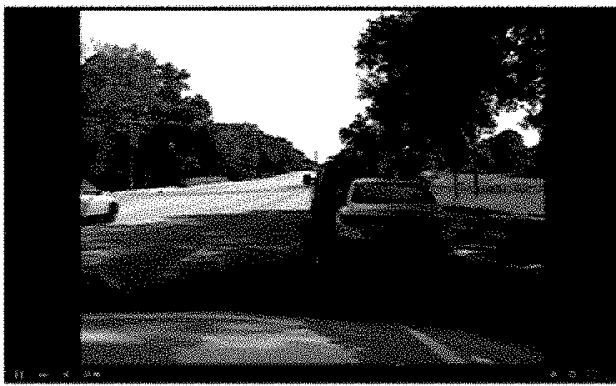

Sandra Biand traflic step

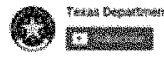

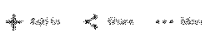

When

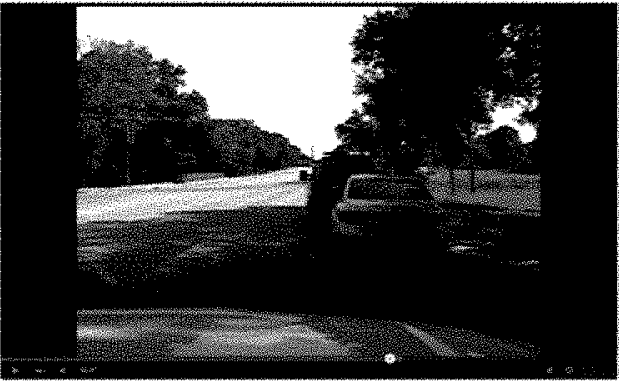

Sandra Bland tratfic stop

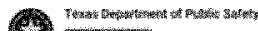

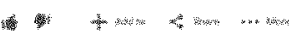

$37 \mathrm{~T}$;

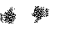

Later in the video, the tow-truck driver walks past the Bland car, then reappears, coming out of his truck in a flash, and then flashes again coming out of his truck and repeats his walk past the Bland car, all the while the background audio of Officer Encinia talking about the arrest is not similarly interrupted or repeated. ${ }^{114}$

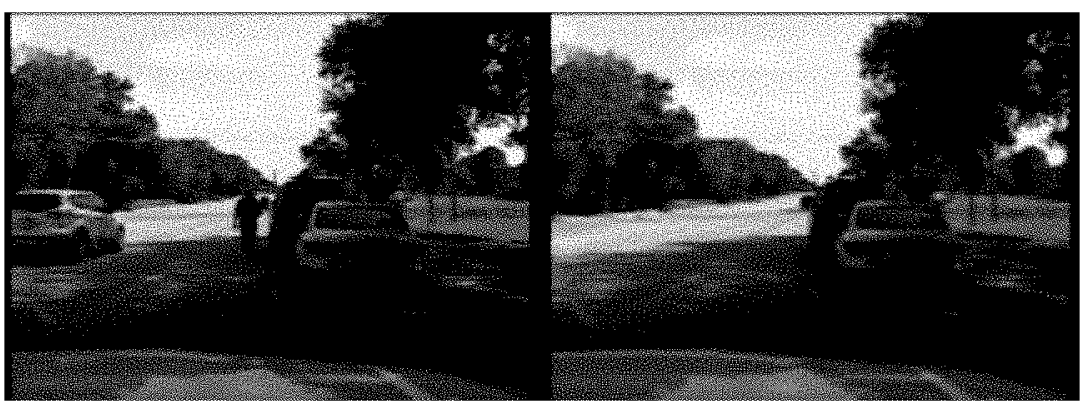

The puzzling circumstances of Sandra Bland's death while in custody have, of course, attracted additional attention to the traffic stop and arrest. It appears that the police believed the dashcam video would "quite

113 Image of the traffic stop and arrest of Sandra Bland, excerpted from the original video $\odot 2015$ Ben Norton, available at Dashcam Video of Violent Arrest of Sandra Bland was Edited, BEN NORTON (July 21, 2015), http://bennorton.com/dashcamvideo-of-violent-arrest-of-sandra-bland-was-edited/.

114 Id. See the side-by-side comparison of the first and second videos of the traffic stop and arrest released by the Texas Dep't of Public Safety, (c) 2015 Los Angeles Times, available at Sandra Bland dashcam video: A side-by-side comparison, YOUTUBE (July 22, 2015), https://www.youtube.com/watch?v=hFXItgzLZQQ. 
obviously" clear the matter up: a person did not immediately cooperate with a police officer's request to put out a cigarette, and did not immediately cooperate with a police officer's request to get out of her car, and therefore she deserved to be screamed at and dragged from her car, handcuffed, and thrown to the ground. I am intentionally wording these actions in a direct manner, because I question the judgment of the Texas Department of Public Safety if it believes that the video shows objectively reasonable behavior of its public servant, Officer Encinia. The police may have thought the release of the video would build their ethos reception (we will show you the whole thing), and pathos reception (a cop was kicked and cursed at while trying to yank a woman from her own car; therefore, have sympathy when he roughly cuffs her, throws her down, and causes her head to hit the ground).

The edited and altered nature of the video further teaches a lesson about deception and the appearance of impropriety in visual rhetoric. Even though the police eventually released what they represent to be the complete, unedited video, start to finish, of the traffic stop and arrest of Sandra Bland, the fact that altered versions of the video were released first, and, later, further doubts and suspicions arose about the completeness and accuracy of the video recordings of Bland's jail-cell area leading up to her death, cause a breach in the ethos perception of anything about this case that has been issued by the Texas Department of Public Safety. Visual rhetoric is powerful, but the careless use of visuals can work a powerful harm on the perception of your truthfulness and candor when you play fast and loose with the content of your material.

Ultimately, if the lawsuit brought by the heirs of Sandra Bland continues, counsel for both sides will have to make the determination whether seeing the actual events of the traffic stop and arrest of Bland is advantageous in assisting the audience to understand the events of that morning leading up to the lawsuit. It is extremely likely that both sides will try to make use of the video, because, as in the case of the Scott video, it is the only record of the events. Counsel for defendant Encinia and the Sheriff's Department will have to do more than "medium mood control"115 to control for the ethos impact of having first released an altered video and then the unaltered edition. The video footage itself is unlikely to presented by either side without a narrator because, cognitive illiberalism and naïve realism aside, the video does not speak for itself. Officer Encinia's counsel will have to explain why it was appropriate to get so physical with a 
verbally uncooperative motorist; Bland's heirs' counsel will want to emphasize the steps of the encounter that led to her arrest and being taken into custody.

Stills taken from the bystander video can be used to show the unexpected occurrence of being forced to the ground and roughly handcuffed for a traffic stop arising from a motorist's failure to signal a lane change. These visuals may speak for themselves, as it is undeniable that Bland wound up being forced to the ground in pain and discomfort when the bystander video is paired with the audio recording of the officer's offcamera actions.

\section{F. Heavy-Handed Uses of Visuals in Closing Arguments of Criminal Cases}

In five of the six examples discussed above, counsel made use of preexisting visual devices-photographs or video recordings-that were then employed to assist the counsel in making an argument about the case to an audience. In the sixth example, United States v. Apple, the Kohn Cartoon Brief was created by Kohn, but he chose not to create visuals related to the subject matter of the case; rather, he placed an entirely verbal argument in the context of five pages of cartoon-based sequential storytelling. This section discusses the wholesale creation of a visual device to make an argument in a case.

Scholars have commented on the heavy-handed technique of prosecutors who created self-generated visual elements for their arguments to the jury in cases ranging from the American murder trial of Kennedy cousin Michael Skakel, ${ }^{116}$ to the Italian murder trial of American expatriate Amanda Knox. ${ }^{117}$ In both of these cases, the prosecutors constructed visual and audiovisual exhibits that were presented as "argument" in the closing arguments of each case in an attempt to convince the juries that the prosecutors had proved the true account of the crimes and who committed them.

Michael Skakel is the nephew of Ethel Kennedy, the widow of Robert F. Kennedy. He was a suspect in the 1975 murder of his neighbor, Martha Moxley. Both Skakel and victim Martha Moxley were fifteen years old at the time and lived near each other in Greenwich, Connecticut. Prosecutors claimed Skakel killed Moxley in a jealous rage. The evidence 
was limited, and certain observers believed that Skakel's connections to the Kennedy clan caused prosecutors to go easy on the boy. Eventually, a state trial-court judge conducted a personal investigation in the late $1990 \mathrm{~s}$ and apparently assembled enough evidence to convince the Connecticut prosecutors to charge and try Skakel in 2000. Skakel was convicted in 2002. After several rounds of appeals and a habeas corpus petition, in October 2013, Skakel was awarded a new trial and freed on bond. ${ }^{118}$

In the Michael Skakel trial, prosecutors created a sophisticated PowerPoint with embedded video and animated text excerpted from Skakel's testimony at trial and from interviews reported in the press to highlight certain of his words that were then interwoven and shown on the screen at the same time as images from the crime scene and the victim's murdered corpse. The images and testimony were separated by twentyfive years, but the PowerPoint's animation and embedded video suggested that Skakel's words of "panic" were linked to the discovery of the murder victim's body. ${ }^{119}$
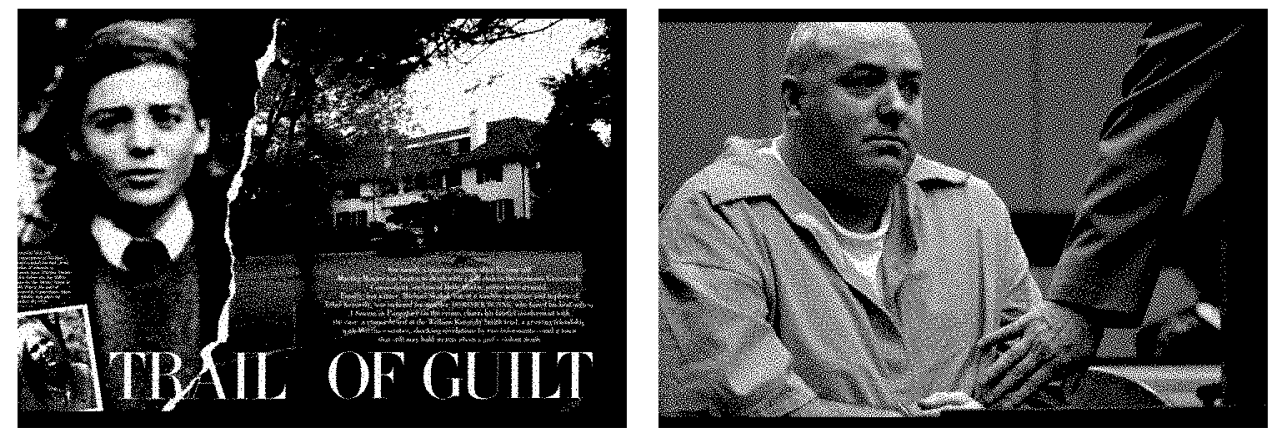

Skakel facing the prosecution's PowerPoint

In the Amanda Knox prosecution in Italy, the Italian prosecutor created a computer animation depicting what he had argued were the facts and events of the evening that Knox's roommate, Meredith Kercher, was brutally murdered. Although rendered in somewhat clumsy, cartoonlike $3 \mathrm{D}$ animation, the video displayed the completely one-sided narrative suggested by the prosecution: first, depicting the victim drinking with Knox's friends; then showing an argument between Kercher, Knox, and Knox's Italian boyfriend, Raffaele Sollecito; next depicting a brutal attack

118 See Michael Skakel Fast Facts, CNN LIBRARY (Sep. 5, 2015, 9:42 AM ET), http://www.cnn.com/2013/05/27/us/michaelskakel-fast-facts/.

119 See sources cited supra note 114. Images on this page are excerpted from (1) original photograph $\odot 2000$ by Vanity Fair, available at http:/www.vanityfair.com/news/2000/10/dominick-dunne-martha-moxley-murder-greenwich; and (2) original photograph @ 2013 by Jessica Hill \& Associated Press, available at http://www.nydailynews.com/news/national/michaelskakel-stay-prison-murder-retrial-article-1.1508510. 
by Knox and Sollecito on Kercher-animated with a great deal of blood to match the actual bloodiness of the crime scene; and finally depicting certain actions taken by Knox and Sollecito allegedly to create a false cover story of a violent break-in by a burglar. ${ }^{120}$
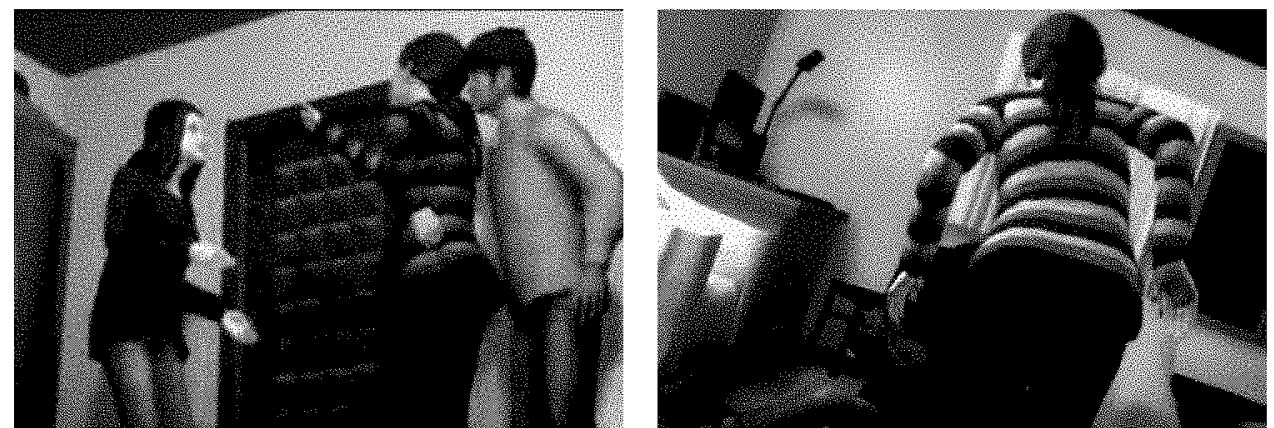

Amanda Knox trial animation of the prosecution's version of the events of the night of the murder ${ }^{121}$

The fact that in both the Skakel example and the Knox example the prosecutors created the visuals themselves makes these examples more indicative of the ethical implications of the decisions I have been discussing here. With a dashcam video, there rarely is any suggestion that the police "authored" the video in the sense that they created and recorded (or staged) the conduct that appears on the video. The video camera is understood to be a passive observer of events unfolding before the patrol car, much like a passive security camera will record the events taking place in one $50^{\prime}$ by $60^{\prime}$ area behind a warehouse. Evidence of after-the-event editing of the video thus properly raises a large red flag because the value of the passive recording is in its completeness; in other words, that the one-perspective view of the events is, at least, a complete record of the events that took place in that area where the camera was pointed and during the time period in question. Once an attorney becomes an author, the pressure is on to make sure that the attorney's authored and created "record" accurately portrays or demonstrates the actual events known to the attorney and her witnesses. Once a visual is created, it is likely to be accepted by the audience-that is how our cognitive biases work-and once it makes an impression on the audience's comprehension of the events, it is very difficult to overthrow that impression with rebuttal testimony or counterargument. ${ }^{122}$

120 Sherwin, Visual Jurisprudence, supra note 4 , at 13 .

121 Images on this page are excerpted screenshots from the original video created by or for the Italian prosecutors in the Italian prosecution of Amanda Knox, republished by Apple Daily Taiwan, available at https://www.youtube.com /watch?v=DrxylYMiMVM.

122 See sources cited in note 69, supra. 
The use of rhetoric should create knowledge and understanding by constructing the actual reality for the audience. It should not be used to construct a false reality. The Knox video contained not a single depiction of the actual evidence in the case. It animated the prosecutors' theory of what transpired in the case. The power of video, even animated video, is that it makes the fanciful and imagined seem completely possible just because the audience can see it with their own eyes: "See, it (could have) happened just this way."

Visual rhetoric deserves additional, careful examination for its ability to exceed the ethical and professional obligations not to put forth evidence and arguments that are unsupported by the facts, or that have the potential to mislead or obscure the facts of the matter. ${ }^{123} \mathrm{I}$ am not intimately aware of the details of either the Skakel or the Knox cases, so I will give the benefit of the doubt to the prosecutors in making their ethical choices. The prosecutors in both cases almost certainly believed that they had proved the facts that constituted their version of the case. The process that led to the closing arguments was the construction of a narrative to weave the facts into a story supporting conviction.

Stories inevitably bridge gaps in the factual record; if the storyteller does not fill in the missing details through the weaving of a plausible narrative, the audience surely will. ${ }^{124}$ This statement reflects both the cognitive power and ethical risk of communicating in a narrative format, but humans are so hardwired to receive and process information in this format that attorneys would be falling short on their professional responsibilities not to communicate in a narrative form. I have no knowledge or information with which to contradict any elements of the prosecutors' stories in the Skakel or Knox cases that were not supported by physical or testimonial evidence. But I can say with equal assurance that part of the stories told by the prosecutors involved inference or conjecture necessary to bridge gaps in the factual record. If the attorneys constructed a false reality for their audiences, they violated their ethical and professional obligations.

The prosecutors in both cases determined that the best way to communicate the narrative leading to conviction was through audiovisual means. In the Skakel case, a presentation was used that linked a transcript of an interview decades after the crime to images and other visual evidence captured or produced at the time of the crime. In the Knox case, an animated depiction of the prosecutors' entire theory of the case was

123 See Murray, Leaping Language, supra note 11, at 74; Johansen \& Robbins, supra note 89, at 103-05.

124 See Berger, supra note 70, at 276; O’Brien \& Wayland, supra note 70, at 765-66; Stratton, supra note 70, at 934; Patten, supra note 70 , at 242 . 
created. The boldness of the prosecutions' efforts looks even more stark because the defense in each case apparently did not rise to the occasion and bring forth an equally compelling visual counter-narrative. The jury in the Skakel case saw connections being made whose significance was aggrandized by the flashy visual presentation. The finders of fact in the Knox case witnessed only one complete, coherent explanation of the case: that of the prosecutor, who animated his theory and presented it to his audience. The audience might have thought, "This is only one theory of the case, and this depiction is just one possible depiction as seen through the eyes of the prosecution." But that statement itself would be misleading, because the power of the complete visual presentation of the case is that it does not read to the audience as being "one version of the events - the prosecutors' version." Instead, the heuristic of naïve realism aids the finder of fact to conclude, "That's the story. I can see it for what it is. It quite obviously must be the truth."

For these reasons, the completely "authored" visual raises the most concerns regarding an attorney's ethical and professional obligations. To raise the concern is to remind counsel to be vigilant and scrupulous in sticking to the facts as known to the counsel and her witnesses, and letting the visual perform powerfully toward communicating the truth to the audience. Visual rhetorical devices are a proper form of legal rhetoric if they are used to construct knowledge and understanding of the meaning and message of the communication and do not mislead or prejudice the audience's reception or understanding of the communication.

\section{Conclusion}

Rhetoric is the study of the best available means to communicate in a rhetorical situation, a situation where the speaker can make a difference with her communication, and especially where the matter of the discussion is contested or contestable. Litigation is a perfect example of such a situation, which is why many of the definitions and characterizations revolve around persuasion in a contested matter. ${ }^{125}$ The

\footnotetext{
125 See, e.g., ARISTOTLE, ON RHETORIC: A THEORY OF CIVIC DISCOURSE 35-36 (George A. Kennedy trans., 2d ed. 2007); ARISTOTLE, 1 RHETORIC ch. 2 (W. Rhys Roberts trans., Lee Honeycutt ed, 1965), available at http://www.public.iastate.edu / honeyl/ Rhetoric/ ("Rhetoric may be defined as the faculty of observing in any given case the available means of persuasion.”); JOHN J. MAKAY, SPEAKING WITH AN AUDIENCE: COMMUNICATING IDEAS AND ATTITUDES 11 (1977) ("Rhetoric may be thought of as the process of human communication in which a speaker sorts, selects, and sends symbols for the specific purpose of evoking a precise response from an audience."); KRISTEN K. ROBBINS-TISCIONE, RHETORIC FOR LEGAL WRITERS: THE THEORY AND PRACTICE OF ANALYSIS AND PERSUASION 9 (2009) ("[R]hetoric here refers to the art of persuasion through eloquent, inventive, and strategically organized discourse, both oral and written."); Gerald Wetlaufer, Rhetoric and Its Denial in Legal Discourse, 76 VA. L. REV. 1545, 1546 (1990) ("By 'rhetoric', I mean the discipline ... in which the objects of formal study are the conventions of discourse and argument.").
} 
recognition that visual rhetoric is rapid, efficient, constructive, and persuasive reveals the potential of visual rhetorical devices to serve as topics and tropes in legal discourse to construct meaning and to inform and persuade legal audiences. The visual rhetorical topics and tropes inspire inventive thinking about the law that constructs meaning for the author and the audience.

For many members of the legal writing discourse communityjudges, practitioners, government agencies, and academics-the modes of persuasion of visual rhetoric can construct meaning and improve the persuasiveness of legal discourse generally in content, arrangement, and style. However, the cautions of scholars as to the dangerous power of visuals to deceive or to overpower more deliberative forms of rational thought and analysis are not lightly to be dismissed. The speed and power of visuals is seductive. Visual topics and tropes are subject to abuse and must be used ethically and with careful regard to their propriety as a tool to create meaning and inspire imagination and not as a tool of deception or obfuscation within the rhetorical situation at hand. This, of course, is a lesson for all rhetoricians of legal discourse, whether employing strictly verbal tools of communication and persuasion, or a mixture of verbal and visual tools.

In conclusion, visual rhetorical devices are a proper form of legal rhetoric if they are used to construct knowledge and understanding of the meaning and message of the communication and do not mislead or prejudice the audience's reception or understanding of the communication. 